\title{
Exploring the effect of aminoglycoside guanidinylation on ligands for Tau exon 10 splicing regulatory element RNA
}

Paula López-Senín, Gerard Artigas, and Vicente Marchán*

Departament de Química Orgànica and IBUB, Universitat de Barcelona

Martí i Franquès 1-11, E-08028 Barcelona (Spain)

Fax: + (34) 933397878

E-mail:vmarchan@ub.edu

\begin{abstract}
We describe the effect of guanidinylation of the aminoglycoside moiety on acridine-neamine-containing ligands in the stem-loop structure located at the exon 10-5'intron junction of Tau pre-mRNA, an important regulatory element of tau gene alternative splicing. On the basis of dynamic combinatorial chemistry experiments, ligands that combine guanidinoneamine and two different acridines were synthesized and their RNA-binding properties were compared with those of their amino precursors. Fluorescence titration experiments and UV-monitored melting curves revealed that guanidinylation has a positive effect both on the binding affinity and specificity of the ligands for the stem-loop RNA, as well as on the stabilization of all RNA sequences evaluated, particularly some mutated sequences associated with the development of FTDP-17 tauopathy. However, this correlation between binding affinity and stabilization due to guanidinylation was only found in ligands containing a longer spacer between the acridine and guanidinoneamine moieties, since a shorter spacer produced the opposite effect (e.g. lower binding affinity and high destabilization). Furthermore, spectroscopic studies suggest that ligand binding does not significantly change the overall RNA structure upon binding (circular dichroism) and that the acridine moiety might intercalate near the bulged region of the stem-loop structure (UV-Vis and NMR spectroscopy).
\end{abstract}




\section{Introduction}

RNA has enormous potential as a drug target since it is involved in many essential biological processes including the regulation of transcription and translation, as well as the control of gene expression. From a medicinal chemistry point of view, the ability of RNA to adopt complex three-dimensional architectures by folding local structures (e.g. hairpins, stem-loops, bulges, etc.) provides the oportunity to generate small molecules that could selectively bind and regulate its functions. ${ }^{1}$ Targeting such secondary structures found in miRNA precursors or in pre-mRNA, in most cases well-defined stem-loop structures, is particularly attractive since it would allow us to interfere with miRNA maturation and, for instance, to manipulate miRNA levels or to regulate alternative splicing, respectively. ${ }^{2}$

Despite the enormous potential applications of RNA as a drug target, there are few small molecules with the optimal properties, e.g. high affinity and good specificity for a given RNA sequence. ${ }^{1,3}$ Today, the rational design of RNA ligands continues to be a difficult task mainly due to our poor understanding of RNA recognition principles and to the high conformational dynamics of this macromolecule, which hinders the prediction of tertiary structures and, for instance, the de novo design of RNA ligands. ${ }^{4}$ In addition, it is also important to confer RNAbinding small molecules with pharmacological properties such as cell permeability to generate drug-like molecules. ${ }^{1 b, 5}$ Within this scenario, the combination of small molecules with known RNA-binding properties offers new opportunities for generating RNA ligands with an optimal balance between affinity and specificity. ${ }^{6}$

We have recently described the usefulness of this approach in combination with dynamic combinatorial chemistry (DCC $)^{7}$ to identify ligands for the stem-loop structure located at the exon 10-5' intron junction of Tau pre-mRNA. ${ }^{8}$ In vitro and in vivo experiments had previously demonstrated that this stem-loop structure is an important regulatory element in pre-mRNA splicing since the extent of exon 10 inclusion is inversely proportional to its stability. ${ }^{9}$ The fact that mutations found in patients with frontotemporal dementia with parkinsonism linked to chromosome 17 (FTDP-17) diminish the stability of this stem-loop structure, led to the search for small molecules that selectively bind and stabilize to this structure, in particular the mutated variants. ${ }^{8,10}$ Such compounds are expected to restore the physiological balance of Tau protein isoforms generated upon alternative splicing of the tau gene and, consequently, the tauopathy to be treated. ${ }^{11}$

In our previous work, selected compounds in DCC experiments showed some interesting properties, including high to medium binding affinities, moderate specificities and the ability to stabilize both the wt RNA and some mutated sequences. ${ }^{8}$ The most promising RNA- 
templated ligands combined a small aminoglycoside, neamine (Nea or Nea2 in Scheme 1), and heteroaromatic moieties such as azaquinolone or acridines (Azq, Acr1 or Acr2 in Scheme 1). We hypothesize that such molecules interact with RNA via intercalation of the planar acridine moiety, probably in the bulge of the stem-loop structure, ${ }^{10 c, 12}$ as well as through electrostatic interactions and/or hydrogen bonds between the ammonium groups of the aminoglycoside and the RNA. This combination might be responsible for the stabilization ability but also for the moderate specificities of Tau acridine-neamine ligands.

On the basis of these precedents, we wondered whether guanidinylation of the amino functions in the aminoglycoside moiety of acridine-neamine ligands would allow the affinity, specificity and stabilizing properties to be positively tuned. In fact, guanidinoglycosides, ${ }^{13}$ like naturally occurring aminoglycosides, bind RNA preferentially over DNA and, more importantly, their high binding affinity and ability to discriminate between RNA molecules is substantially improved with respect to their aminoglycoside precursors through this chemical modification. For example, binding of guanidinoneomycin B to an RNA helix from the HIV-1 frameshift site resulted in a considerable increase in the thermodynamic stability of the RNA target (the melting temperature was shifted by at least $10^{\circ} \mathrm{C}$ in the presence of $2 \mathrm{M}$ urea). ${ }^{14} \mathrm{It}$ is also important to consider that the introduction of guanidinium groups into the aminoglycoside scaffold will have a positive effect on the cell permeability of the ligands. ${ }^{15}$ Here we report the synthesis of new Tau RNA ligands that combine guanidinoneamine and acridine moieties together with several biophysical studies on their interaction with RNA. The overall results show that guanidinylation has a positive effect on the binding affinity, specificity and ability of the ligands to stabilize RNA, including the mutated sequences. However, this effect was found to be highly dependent on the length of the spacer between both fragments since a shorter linker had a negative effect both on affinity and on stabilizing capacity. 


\section{Results and Discussion}

\section{Exploring the effect of neamine guanidinylation using Dynamic Combinatorial}

Chemistry. Since a direct correlation between the ligand's amplification in DCC experiments and their binding affinity and stabilizing properties has previously been observed, ${ }^{7,8}$ prior to synthesizing the guanidinylated analogues of acridine-neamine ligands, we decided to carry out a DCC experiment to gain some insight into the effect of guanidinylation on the RNAbinding properties of such ligands.
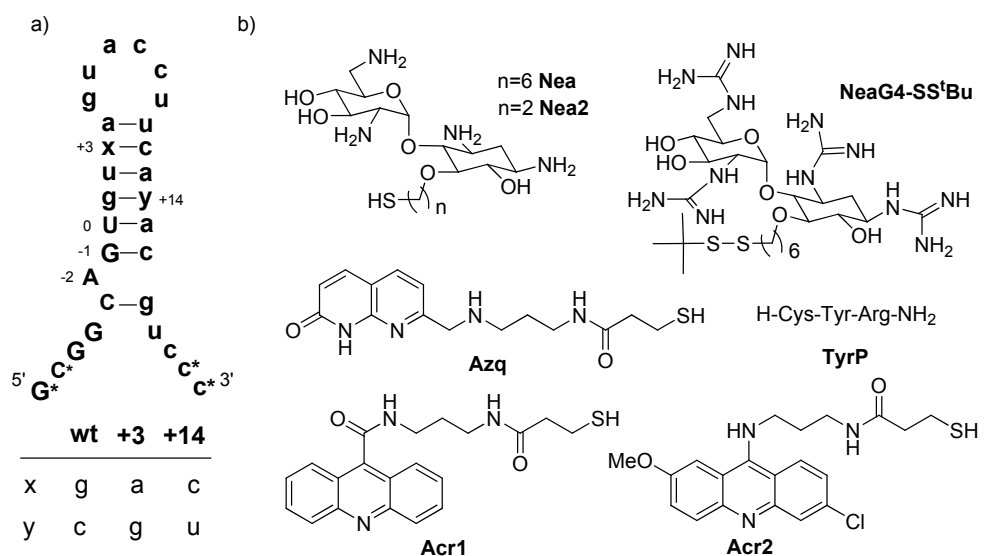

Scheme 1 a) Sequences and secondary structure of wild-type (wt) and +3 and +14 mutated Tau stemloop RNAs. Exonic sequences are shown in capital letters and intronic sequences in lower case. Nucleotides involved in base pairs identified previously by NMR are connected by a dash. ${ }^{9 a}$ When required, biotin or fluorescein derivatization was performed at the 5 ' end. The ends of the chains were modified with 2'-O-methylribonucleosides (denoted by an asterisk). b) Structure and peptide sequence of the building blocks used in the DCC experiments in our previous work ${ }^{8}$ and in the present study.

For this purpose, we planned the synthesis of a new thiol-containing monomer, NeaG4 (Scheme 2), which is the guanidinylated analogue of the neamine monomer containing the longer spacer between the aminoglycoside and the thiol group (Nea in Scheme 1). Nea was reacted with a large excess of $N, N^{\prime}$-di-Boc- $N$ '-triflylguanidine (20 mol eq), a powerful guanidinylating reagent usually employed in the preparation of guanidinoglycosides, ${ }^{16}$ in the presence of dithiothreitol (5 mol eq) and triethylamine (120 mol eq) at RT under an Ar atmosphere (Scheme 2). Once the reaction reached completion (about 4 days), the Bocprotected guanidino derivative, $(\mathbf{B o c})_{\mathbf{8}} \mathbf{N e a G} 4$, was isolated by flash column chromatography and characterized by NMR and MS. After an acidic treatment with a TFA/DCM mixture $(1: 1)$ 
containing TIS and EDT as cation scavengers, the desired NeaG4 derivative was identified as the major compound in the crude mixture by MS-HPLC. However, attempts to isolate it by reversed-phase HPLC were unsuccessful, possibly due to decomposition of the compound upon interaction with $\mathrm{C}_{18}$ stationary phase.

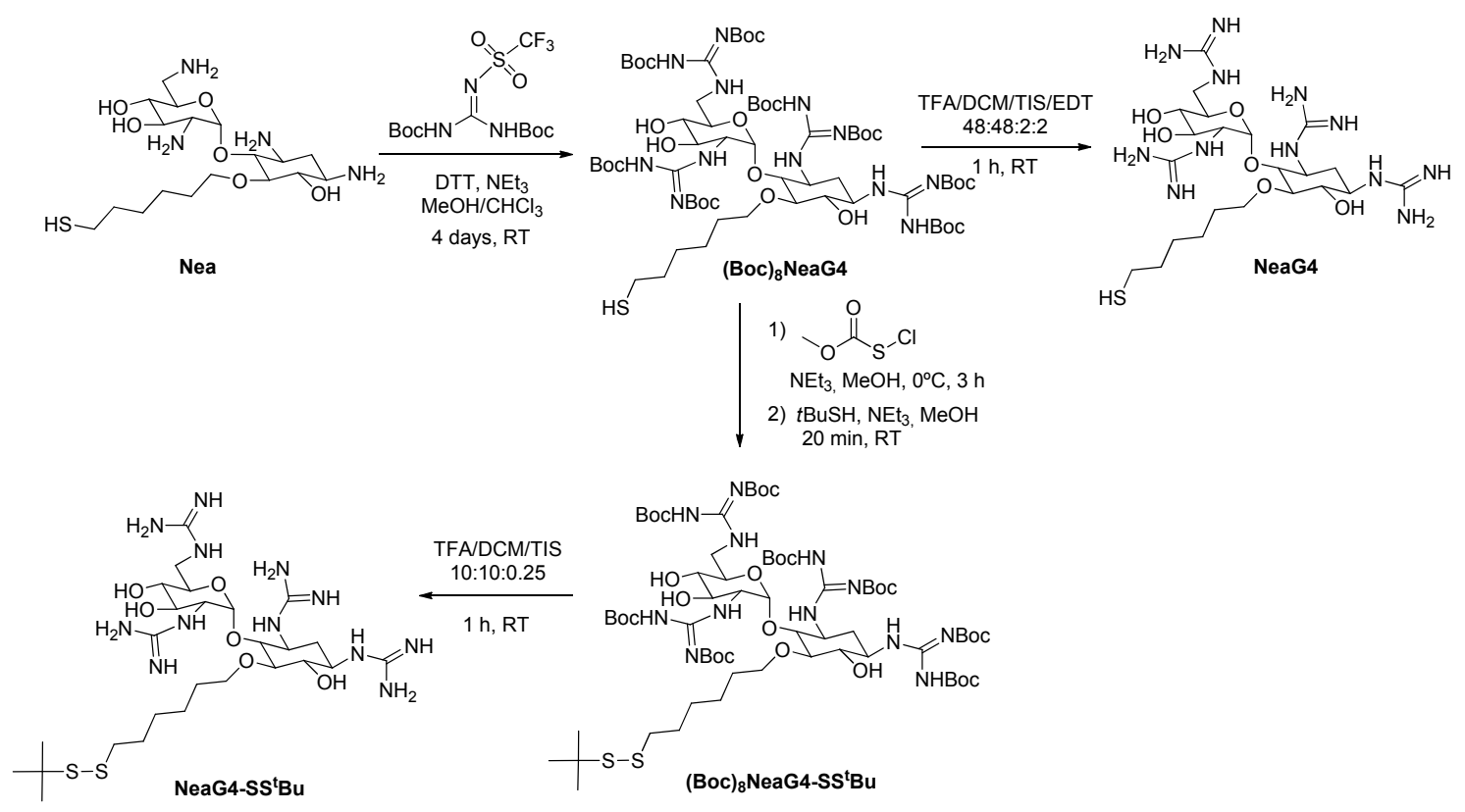

Scheme 2 Synthesis of the guanidinylated neamine monomers NeaG4 and NeaG4-SS ${ }^{\mathbf{t}} \mathbf{B u}$.

We then focused on the synthesis of the tert-butylsulfenyl-protected analogue, NeaG4-SS ${ }^{\mathbf{B}} \mathbf{B u}$ (Scheme 2), since this protecting group has been used in some DCC experiments involving disulphide exchange reactions. ${ }^{6 \mathrm{~d}, 17}$ First, reaction of (Boc) ${ }_{8}$ NeaG4 4 with methoxycarbonylsulphenyl chloride in methanol afforded an activated species that upon treatment with tert-butylthiol in the presence of triethylamine gave the expected tert-butyl disulphide derivative, $\left(\mathbf{B o c}_{\mathbf{8}} \mathbf{N e a G 4 - S S}{ }^{\mathbf{B}} \mathbf{B u}\right.$. Subsequent removal of the Boc-protecting groups with TFA in the presence of TIS afforded the desired monomer, NeaG4-SS ${ }^{\mathbf{t}} \mathbf{B u}$, which was purified by reversed-phase HPLC and characterized by MS.

The DCC experiment ${ }^{8}$ was carried out in aqueous solution with the biotinylated wt RNA target $(25 \mu \mathrm{M})$ and the Nea, Nea2, NeaG4-SS ${ }^{t} \mathrm{Bu}$, Acr2, Azq and TyrP monomers (4 mol eq each; see Scheme 1 for their structures) in Tris-HCl buffer $(50 \mathrm{mM}, \mathrm{pH} 7.7)$ containing $\mathrm{NaCl}$ $(100 \mathrm{mM})$ and EDTA $(0.1 \mathrm{mM})$ at room temperature, under an air atmosphere without stirring. The RNA and the interacting ligands were separated from thiol monomers and other 
non-interacting homo- and heterodimers with streptavidin anchored to magnetic beads using a magnet. The final step of the DCC experiment involved washing the beads with a hot $\left(90^{\circ} \mathrm{C}\right)$ acidic $(0.1 \%$ TFA) aqueous solution to denature the RNA and release RNA-bound ligands, which were then identified and quantified by UV-MS-HPLC (Fig. 1).
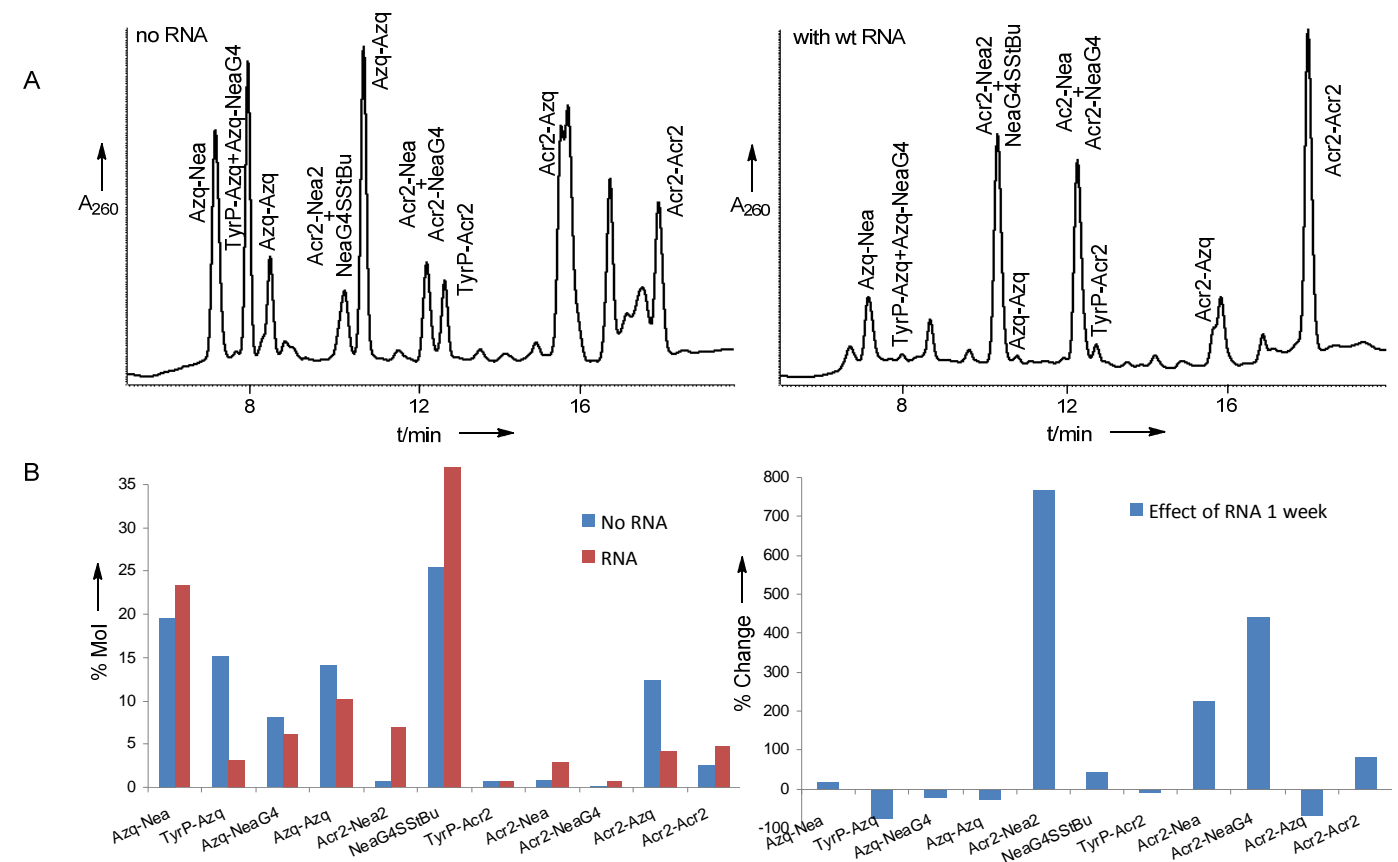

Fig. 1 Results of the DCC experiment involving wt RNA and the Nea, Nea2, NeaG4-SSt Bu, Acr2, Azq and TyrP monomers. A) HPLC traces showing the composition of the DCL in the absence (left) and presence (right) of 5'-biotinylated wt RNA, after 1 week. B) Histograms showing the changes in DCL composition (left) and the percentage changes (\% amplification) of each species (right) in the presence of the wt RNA.

Comparison with the control experiment (RNA free exchange experiment) indicated the amplification of three disulphide heterodimers (Fig. 1): Acr2-Nea2 ( $\approx 800 \%)$, Acr2-Nea $(\approx 250 \%)$ and Acr2-NeaG4 ( $\approx 450 \%)$. To our surprise, a large amount of the NeaG4-SS ${ }^{t} \mathrm{Bu}$ monomer remained unaltered after 1 week of incubation. This observation reveals that the disulphide exchange with the tert-butylsulphenyl protected monomer was not efficient under the air-mediated oxidation conditions employed for carrying out the DCC experiments. Despite the fact that a true thermodynamic equilibrium was not reached after 1 week of incubation, neither in the presence nor in the absence of RNA, two conclusions can be drawn from these results. First, as previously found, ligands incorporating the Acr2 fragment are amplified in much higher proportions than those containing other heteroaromatic moieties 
such as Azq or Acr1. ${ }^{8}$ This confirms the high binding affinity of Acr2-containing ligands for Tau RNA, particularly when this acridine is combined with the neamine monomer that contains the shorter spacer between the thiol group and the aminoglycoside core (e.g. Acr2Nea2 amplification was three-fold higher than that of Acr2-Nea). Second, despite the fact that a large amount of the NeaG4-SS ${ }^{t} \mathrm{Bu}$ monomer did not participate in the disulphide exchange reactions, the amplification of the guanidinylated analogue of Acr2-Nea, namely Acr2NeaG4, was substantially higher, thereby suggesting a high binding affinity for wt RNA. Hence, we can conclude from these DCC results that replacement of the amino functions by guanidinium groups in the aminoglycoside moiety in ligands containing both acridine and neamine fragments might have a positive effect on their binding affinity.

Synthesis of the guanidinylated ligands. On the basis of the DCC results, we planned the synthesis of the guanidinylated analogues of three acridine-neamine compounds previously identified as Tau RNA ligands: Acr1-Nea, Acr2-Nea and Acr2-Nea2. ${ }^{8}$ The structures of the parent ligands as well as of their guanidinylated analogues (Acr1-NeaG4, Acr2-NeaG4 and Acr2-Nea2G4, respectively) are shown in Scheme 3. For comparison purposes, the length and the type of linkage between the aminoglycoside and the acridine moieties were the same as those of the non-guanidinylated ligands (e.g. a disulphide linkage in Acr2-Nea2G4 and the thioether isostere $\left(\mathrm{CH}_{2}-\mathrm{S}\right)$ in Acr1-NeaG4 and Acr2-NeaG4).

Synthesis of the Acr1-NeaG4 ligand was carried out by reaction between the thiol-containing Boc-protected guanidinoneamine and the acryloyl-derivatized acridine (Scheme 3 ) in the presence of a slight excess of sodium hydride ( $3 \mathrm{~mol} \mathrm{eq}$ ) for $4 \mathrm{~h}$ at RT under Ar. The Bocprotected guanidinylated intermediate was treated with a 1:1 mixture of TFA/DCM in the presence of TIS and EDT to afford the desired Acr1-NeaG4 ligand after reversed-phase MPLC purification (two-step yield: 20\%). Acr2-NeaG4 and Acr2-Nea2G4 were prepared by direct guanidinylation of their precursors, Acr2-Nea and Acr2-Nea2G4, respectively, following the procedure used for the synthesis of (Boc) $)_{\mathbf{8}}$ NeaG4. A 40-fold mol eq excess of $N, N$ '-di-Boc- $N$ "'-triflylguanidine in the presence of $\mathrm{NEt}_{3}$ was used in both cases, and after acidic deprotection and HPLC purification, the desired ligands were obtained: Acr2-NeaG4 (yield: 56\%) and Acr2-Nea2G4 (yield: 20\%). In conclusion, both the conjugate addition of (Boc) $)_{\mathbf{8}}$ NeaG4 over the acryloyl-derivatized acridine and the direct guanidinylation of the amino-precursors allow the synthesis of guanidinoneamine-acridine ligands with moderate yields. 


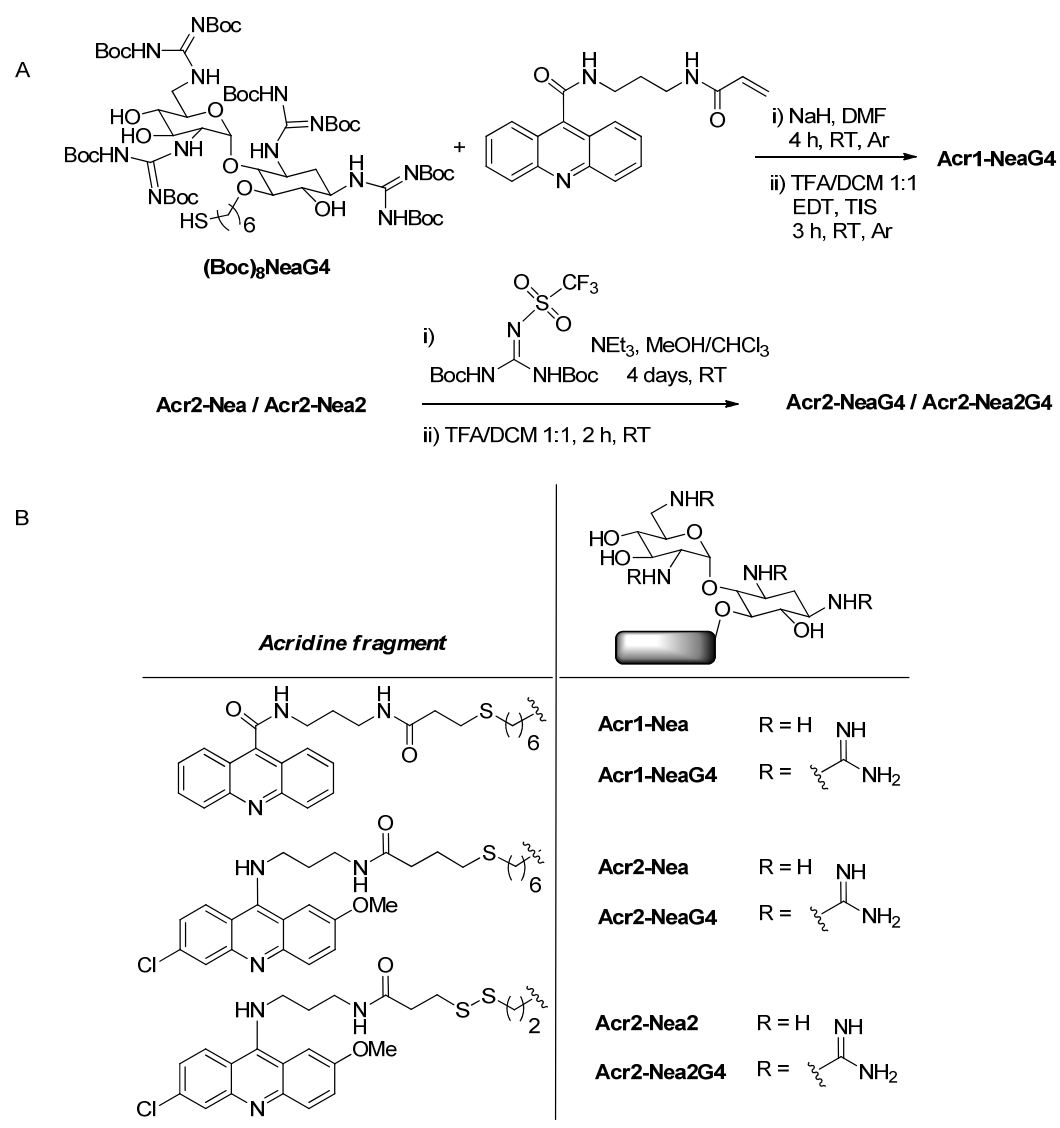

Scheme 3 Synthesis (A) and schematic representation of the structure (B) of the guanidinylated and non-guanidinylated ligands.

Binding affinities and specificities of the guanidinylated ligands. The binding affinity of the guanidinylated ligands was determined by fluorescence titration experiments. ${ }^{18}$ Wild-type RNA was labelled with fluorescein and, upon excitation at $490 \mathrm{~nm}$, the fluorescence intensity was monitored as a function of the increase in the concentration of the ligand (typically from 0.0005 to 3000 mol equivalents, depending on the ligand's affinity). In all cases, a characteristic dose-dependent saturatable quenching in the fluorescence of RNA was observed (Fig. 2A), which was attributed to conformational changes in the RNA upon complexation with the ligands. The inherent fluorescence of the ligand was always subtracted from that of labelled RNA by repeating the full titration in the absence of RNA. Finally, $\mathrm{EC}_{50}$ values (the effective ligand concentration required for $50 \%$ RNA response) were obtained by fitting the data to a sigmoidal dose-response curve (Fig. 2B). 

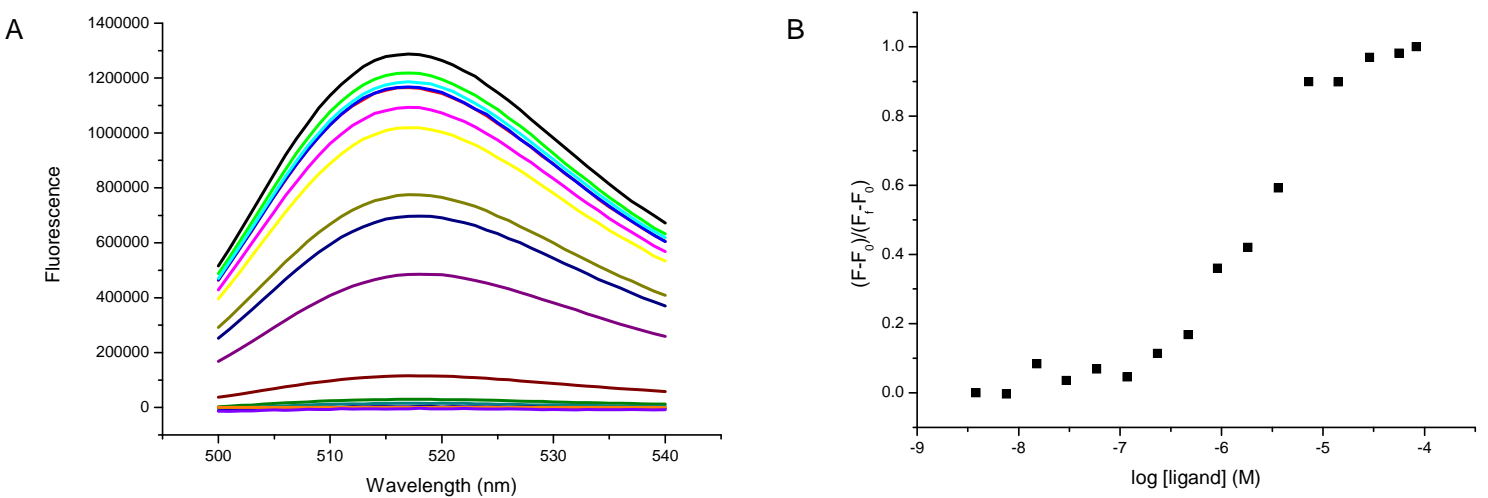

Fig. 2 (A) Fluorescence quenching of wt RNA labelled with fluorescein upon addition of increasing concentrations of Acr2-NeaG4. Measurements were performed with an RNA concentration of 0.25 $\mu \mathrm{M}$ and ligand concentrations ranging from 0 (black) to 83.2 (blue) $\mu \mathrm{M}$ in $10 \mathrm{mM}$ sodium phosphate buffer pH 6.8, $100 \mathrm{mM} \mathrm{NaCl}$ and $0.1 \mathrm{mM} \mathrm{Na}_{2}$ EDTA. (B) Plot of the normalized fluorescence signal at $517 \mathrm{~nm}$ against the log of Acr2-NeaG4 concentration. $F_{o}$ is the initial fluorescence of fluoresceinlabelled RNA, $F_{f}$ is the final fluorescence of the RNA and $F$ is the observed fluorescence.

The $\mathrm{EC}_{50}$ values of the three guanidinoneamine-acridine ligands together with those of their amino precursors are shown in Table 1. As a control, neamine and guanidinoneamine binding affinities for wt RNA were also determined. Consistent with our previous results, ${ }^{8}$ guanidinylated ligands containing the Acr2 moiety showed higher binding affinities than the ligand containing Acr1 (e.g. $\mathrm{EC}_{50}=2.4 \mu \mathrm{M}$ for Acr2-NeaG4 vs. $\mathrm{EC}_{50}=18.9 \mu \mathrm{M}$ for Acr1NeaG4). As expected based on the DCC results, the guanidinylation of the four amino groups of neamine had a positive effect on the binding affinity of Acr1-Nea and Acr2-Nea. Indeed, the $\mathrm{EC}_{50}$ value for Acr1-NeaG4 was 1.5 times higher than for Acr1-Nea, and this effect was even higher (about 2.5 times) when comparing the values of Acr2-NeaG4 and Acr2-Nea. To our surprise, the $\mathrm{EC}_{50}$ value of the guanidinylated ligand containing the shorter spacer between acridine and neamine, Acr2-Nea2G4, was higher than that of Acr2-Nea2, which indicates that in this case guanidinylation had a negative influence on binding affinity. This effect was the opposite of that previously found with non-guanidinylated ligands, since the affinity was approximately three times higher for Acr2-Nea2 than for Acr2-Nea. As expected, the binding affinity of guanidinoneamine for wt RNA was substantially higher than that of neamine. The fact that this effect was stronger than that found in acridine-neamine ligands could be attributed to the high promiscuity of small amino- and guanidinoglycosides alone, which could have several binding sites in our RNA target. However, the effect of 
guanidinylation on the binding affinity of ligands combining acridine and neamine may be strongly influenced by the existence of a preferred binding site for their non-guanidinylated precursors in the RNA target, probably driven in our case by intercalation of the heteroaromatic fragment. ${ }^{8,10,12}$ The opposite effect of guanidinylation on Acr2-Nea and Acr2Nea2 suggests that the introduction of four guanidinium groups into the ligand with the shortest spacer might generate sterical hindrance, leading to a loss of affinity. However, the longer distance between the two fragments in Acr1-NeaG4 or in Acr2-NeaG4 would not impede the optimal accommodation of acridine and guanidinoneamine in the stem-loop RNA structure, leading to an increase in affinity due to the positive effect of the guanidium groups.

Table 1. Binding of the ligands to wt RNA in the absence or in the presence of a tRNA competitor.

\begin{tabular}{cccc}
\hline Ligand & $\begin{array}{c}\mathrm{EC}_{50} \\
(\mu \mathrm{M})^{[\mathrm{a}]}\end{array}$ & $\begin{array}{c}\mathrm{EC}_{50}(\mu \mathrm{M}) \\
+\mathrm{tRNA}^{[\mathrm{b}]}\end{array}$ & $\begin{array}{c}\mathrm{EC}_{50}+\mathrm{tRNA} \\
/ \mathrm{EC}_{50}\end{array}$ \\
\hline Neamine & 3100 & $\mathrm{nd}$ & $\mathrm{nd}$ \\
Guanidinoneamine & 830 & $\mathrm{nd}$ & $\mathrm{nd}$ \\
Acr1-Nea & 28.6 & 112.2 & 3.9 \\
Acr1-NeaG4 & 18.9 & 45.5 & 2.4 \\
Acr2-Nea & 5.9 & 63.1 & 10.7 \\
Acr2-NeaG4 & 2.4 & 24.9 & 10.4 \\
Acr2-Nea2 & 2.1 & 47.0 & 22.4 \\
Acr2-Nea2G4 & 3.6 & 50.9 & 14.1 \\
\hline
\end{tabular}

[a] All fluorescence measurements $(0.25 \mu \mathrm{M}$ RNA) were performed in $10 \mathrm{mM}$ sodium phosphate buffer pH 6.8, $100 \mathrm{mM} \mathrm{NaCl}$ and $0.1 \mathrm{mM} \mathrm{Na}_{2}$ EDTA. [b] Measured in the presence of a 30-fold nucleotide excess of a mixture of tRNA (tRNA ${ }^{\text {mix }}$ ).

Fluorescence binding assays were repeated in the presence of a large excess (30-fold nucleotide excess) of a tRNA ${ }^{\text {mix }}$ from baker's yeast that contains a mixture of pre- and mature tRNAs. These competitive experiments allow the specificity of the ligands to be determined, according to the ratio between the $\mathrm{EC}_{50}$ value in the presence of the competitor and the $\mathrm{EC}_{50}$ value in the absence of the competitor. ${ }^{18 b, 19}$ Again, the specificity of the guanidinylated ligands was shown to be highly dependent both on the nature of the acridine building block and on the distance of the spacer between the acridine and the guanidinoneamine units. In the presence of the competitor, the $\mathrm{EC}_{50}$ values of Acr2-NeaG4 and Acr2-Nea2G4 for Tau RNA were increased by 10-fold and 14-fold, respectively, whereas that of Acr1-NeaG4 was only increased by 2.4 -fold. Hence, the Acr1 moiety confers higher specificity to acridineguanidinoneamine-containing ligands in comparison with Acr2. This behaviour was similar to 
that shown by non-guanidinylated ligands, since Acr1-Nea was more specific for Tau RNA than Acr2-Nea/Nea2. Interestingly, guanidinylation of Acr1-Nea and Acr2-Nea2 had a positive effect on the specificity of both ligands since the specificity ratio of Acr1-NeaG4 and Acr2-Nea2G4 was reduced about 1.5-fold when compared with that of their amino precursors. However, a similar specificity ratio was obtained for Acr2-Nea and Acr2-NeaG4. As shown in Table 1, the specificity ratio for Acr2-Nea2G4 was higher than that of Acr2-NeaG4, showing a similar trend to their non-guanidinylated precursors, Acr2-Nea and Acr2-Nea2. The overall results indicate that guanidinylation of acridine-neamine ligands has a positive (Acr1-NeaG4 and Acr2-Nea2G4) or minimal (Acr2-NeaG4) effect on their specificity for Tau RNA. In addition, a longer spacer always confers higher specificity to Acr2-containing ligands, either non-guanidinylated, as previously reported (Acr2-Nea vs. Acr2-Nea2) ${ }^{8}$ or guanidinylated (Acr2-NeaG4 vs. Acr2-Nea2G4), thus differing from the trend found in acridine-neomycin ligands with the HIV-1 RRE RNA target. ${ }^{19 b, 20}$ It is interesting that no correlation between affinity and specificity was found in guanidinylated Acr2-containing ligands, since the ligand with the highest affinity (Acr2-NeaG4) was also the most specific. This trend contrasts with that found in their non-guanidinylated precursors, in which there was an inverse correlation between the two parameters.

\section{Effect of the guanidinylated ligands on the thermal stability of Tau RNA targets. Our} next objective was to evaluate the ability of the guanidinylated ligands to stabilize Tau RNA targets, in particular some of the mutated sequences associated with FTDP-17 development. The thermal stability of the stem-loop structures (wt and +3 and +14 mutants) was determined by UV melting experiments by monitoring the absorbance as a function of temperature. The midpoint of the transition (see Figures S1-S3 in the Supporting Information) is referred to as the melting temperature $\left(T_{m}\right)$, which is indicative of the thermal stability of the RNA secondary structure. As shown in Table $2, \Delta \mathrm{T}_{\mathrm{m}}$ values indicate the effect of the ligands on the thermal stability of RNA upon complexation, whereas $\Delta \mathrm{T}_{\mathrm{m}} \mathrm{G}$ indicate the effect of guanidinylation compared with that of the parent non-guanidinylated ligand.

As with non guanidinylated ligands, replacement of Acr1 by Acr2 in the acridineguanidinoneamine ligands with the longest spacer caused an increase in the $T_{m}$ value of all RNAs. This increase was particularly high for the $+3\left(\Delta \mathrm{T}_{\mathrm{m}}=+5.9^{\circ} \mathrm{C}\right.$ with Acr2-NeaG4 vs. $\Delta \mathrm{T}_{\mathrm{m}}=+2.9^{\circ} \mathrm{C}$ with Acr1-NeaG4) and the +14 mutants $\left(\Delta \mathrm{T}_{\mathrm{m}}=+2.6^{\circ} \mathrm{C}\right.$ with Acr2-NeaG4 vs. $\Delta \mathrm{T}_{\mathrm{m}}=+1.2^{\circ} \mathrm{C}$ with Acr1-NeaG4). As shown in Table 2, guanidinylation of Acr1-Nea or Acr2-Nea always had a positive effect on the thermal stability of all RNAs upon 
complexation with the ligands, particularly with the +3 mutant $\left(\Delta \mathrm{T}_{\mathrm{m}} \mathrm{G}=+1.7^{\circ} \mathrm{C}\right.$ for Acr1NeaG4 and $\Delta \mathrm{T}_{\mathrm{m}} \mathrm{G}=+3.1^{\circ} \mathrm{C}$ for Acr2-NeaG4). The fact that no significant additional stabilization was provided by guanidinoneamine compared to neamine suggests that both aminoglycosides might interact with Tau RNA through the major groove or with the loop. However, the interaction of the heteroaromatic moiety of the acridine-guanidinoneamine ligands within the duplex of the stem-loop structure (see below) through an intercalative or stacking mechanism might be responsible for the optimal allocation of the guanidinoneamine fragment, thereby causing significant changes in RNA $T_{m}$ values. To our surprise, the $T_{m}$ values of all RNAs were clearly decreased (e.g. $\Delta \mathrm{T}_{\mathrm{m}} \mathrm{G}=-2.8^{\circ} \mathrm{C}$ with the +3 mutant, see Table 2) in the presence of the guanidinylated ligand with the shortest spacer, Acr2-Nea2G4. In some cases, the ability of this ligand to stabilize wt RNA or the mutant sequences was even lower than that of the non-guanidinylated ligands with the longest spacer, Acr1-Nea or Acr2Nea.

Taken together, these results show a good correlation between binding affinities of the guanidinylated ligands and their ability to stabilize target Tau RNAs. Indeed, the $T_{m}$ values of all RNAs were clearly increased in the presence of the guanidinylated ligands (Acr1-NeaG4 or Acr2-NeaG4) that had shown higher binding affinities than their non-guanidinylated precursors (Acr1-Nea and Acr2-Nea, respectively). The increase both in the affinity and stabilizing ability of such ligands can be explained by the generation of a strong synergism upon linking guanidineamine and acridine through a long spacer. ${ }^{19 \mathrm{~b}, 21}$ The length and flexibility provided by the spacer would favour the establishment of stabilizing interactions such as hydrogen bonds and/or electrostatic interactions between guanidinium groups and RNA, as well as the optimal orientation of the heteroaromatic moieties. Interestingly, guanidinylation of the ligand with the shortest spacer, Acr2-Nea2, led to a substantial decrease both in the binding affinity and in its capacity to stabilize RNAs, particularly the +3 and +14 mutants. As previously mentioned, this may be due to the proximity of the two fragments in Acr2-Nea2G4, which could hinder not only the most favorable interactions of the guanidinium groups with RNA but also the proper orientation of the acridine moiety in the stem-loop structure via intercalation or stacking. The loss in stabilization capacity of this ligand compared to its amino precursor supports the second explanation. All these observations highlight the importance of the spacer linking two entities in modularly assembled RNA ligands, since their relative orientation determines their RNA binding 
properties. Since the optimal molecular arrangement of a ligand can also be dramatically perturbed by guanidinylation, it is important to carefully select the amino groups to be guanidinylated since otherwise this chemical modification could negatively affect RNAbinding properties.

Table 2. Melting temperatures $\left(T_{m}\right)$ for the complexation of ligands with target RNAs $(1 \mu \mathrm{M}$ both in RNA and in ligands in $10 \mathrm{mM}$ sodium phosphate buffer, $\mathrm{pH} 6.8,100 \mathrm{mM} \mathrm{NaCl}$ and $0.1 \mathrm{mM}$ $\mathrm{Na}_{2}$ EDTA).

\begin{tabular}{cccccccccc}
\hline & $\mathrm{T}_{\mathrm{m}} \mathrm{wt}$ & $\Delta \mathrm{T}_{\mathrm{m}}{ }^{[\mathrm{a}]}$ & $\Delta \mathrm{T}_{\mathrm{m}} \mathrm{G}^{[\mathrm{b}]}$ & $\mathrm{T}_{\mathrm{m}}+3$ & $\Delta \mathrm{T}_{\mathrm{m}}{ }^{[\mathrm{a}]}$ & $\Delta \mathrm{T}_{\mathrm{m}} \mathrm{G}^{[\mathrm{b}]}$ & $\mathrm{T}_{\mathrm{m}}+14$ & $\Delta \mathrm{T}_{\mathrm{m}}{ }^{[\mathrm{a}]}$ & $\Delta \mathrm{T}_{\mathrm{m}} \mathrm{G}^{[\mathrm{b}]}$ \\
\hline No ligand & 66.4 & - & - & 50.8 & - & - & 54.0 & - \\
Neamine & 67.6 & +1.2 & - & 51.8 & +1.0 & - & 54.4 & +0.4 & - \\
Guanidinoneamine & 67.7 & +1.3 & +0.1 & 52.2 & +1.4 & +0.4 & 54.5 & +0.5 & +0.1 \\
Acr1-Nea & 67.1 & +0.7 & - & 52.0 & +1.2 & - & 54.1 & +0.1 & - \\
Acr1-NeaG4 & 68.0 & +1.6 & +0.9 & 53.7 & +2.9 & +1.7 & 55.2 & +1.2 & +1.1 \\
Acr2-Nea & 68.5 & +2.1 & - & 53.6 & +2.8 & - & 56.0 & +2.0 & - \\
Acr2-NeaG4 & 68.7 & +2.3 & +0.2 & 56.7 & +5.9 & +3.1 & 56.6 & +2.6 & +0.6 \\
Acr2-Nea2 & 68.8 & +2.4 & - & 56.5 & +5.7 & - & 57.2 & +3.2 & - \\
Acr2-Nea2G4 & 67.2 & +0.8 & -1.6 & 53.7 & +2.9 & -2.8 & 54.5 & +0.5 & -2.7 \\
\hline
\end{tabular}

[a] $\Delta \mathrm{T}_{\mathrm{m}}=\left(\mathrm{T}_{\mathrm{m}}\right.$ of the RNA in the presence of ligand $)-\left(\mathrm{T}_{\mathrm{m}}\right.$ of RNA alone $)$.

[b] $\Delta \mathrm{T}_{\mathrm{m}} \mathrm{G}=\left(\mathrm{T}_{\mathrm{m}}\right.$ of the RNA in the presence of the guanidinylated ligand $)-\left(\mathrm{T}_{\mathrm{m}}\right.$ of the RNA in the presence of the parent non-guanidinylated ligand).

\section{Spectroscopic studies of the complexes formed between Tau RNA and the}

guanidinylated ligands. The overall results indicate that guanidinylated ligands with the longest spacer between the acridine moieties and neamine, Acr1-NeaG4 and Acr2-NeaG4, showed an adequate balance between affinity, specificity and RNA stabilizing properties. Hence, we wanted to gain some insight into the effect of this chemical modification on the structure of the RNA-ligand complexes in comparison with that of their non-guanidinylated precursors, Acr1-Nea and Acr2-Nea. ${ }^{8}$

First, Acr1-NeaG4 and Acr2-NeaG4 were titrated with increasing quantities of wt Tau RNA to determine whether the acridine moiety has an active role in the interaction with RNA. Consistent with our previous results with non-guanidinylated ligands, strong hypochromism (30-40\%) was observed in the UV-Vis spectra of both ligands in the first stage of the titration 
( 0.2 mol eq of RNA). In addition, both ligands exhibited a shift to higher wavelengths although this effect was smaller for Acr1-NeaG4 (a $2 \mathrm{~nm}$ redshift of the $360 \mathrm{~nm}$ band of the free ligand) than for Acr2-NeaG4 (a 7 and $9 \mathrm{~nm}$ redshift of the 423 and $444 \mathrm{~nm}$ bands of the free ligand, respectively; see Fig. 3). ${ }^{8}$ Such bathochromic effects are commonly observed for DNA or RNA intercalators and suggest that the acridine moiety in both ligands binds the stem-loop structure of Tau RNA through intercalation or stacks with base-pair nucleobases. Interestingly, in the second stage of the titration, the intensities of the two new peaks of the Acr2-NeaG4 ligand (430 and $453 \mathrm{~nm}$ ) increased gradually until saturation was reached. This two-stage binding mode was found by Varani et al. for the mithoxantrone ligand, ${ }^{10 \mathrm{c}}$ and might suggest the allocation of the ligand to a preferred binding site. The fact that this behaviour was not observed with Acr1-NeaG4 might be attributed to the lower binding affinity of this ligand compared with that of the Acr2-containing ligand.
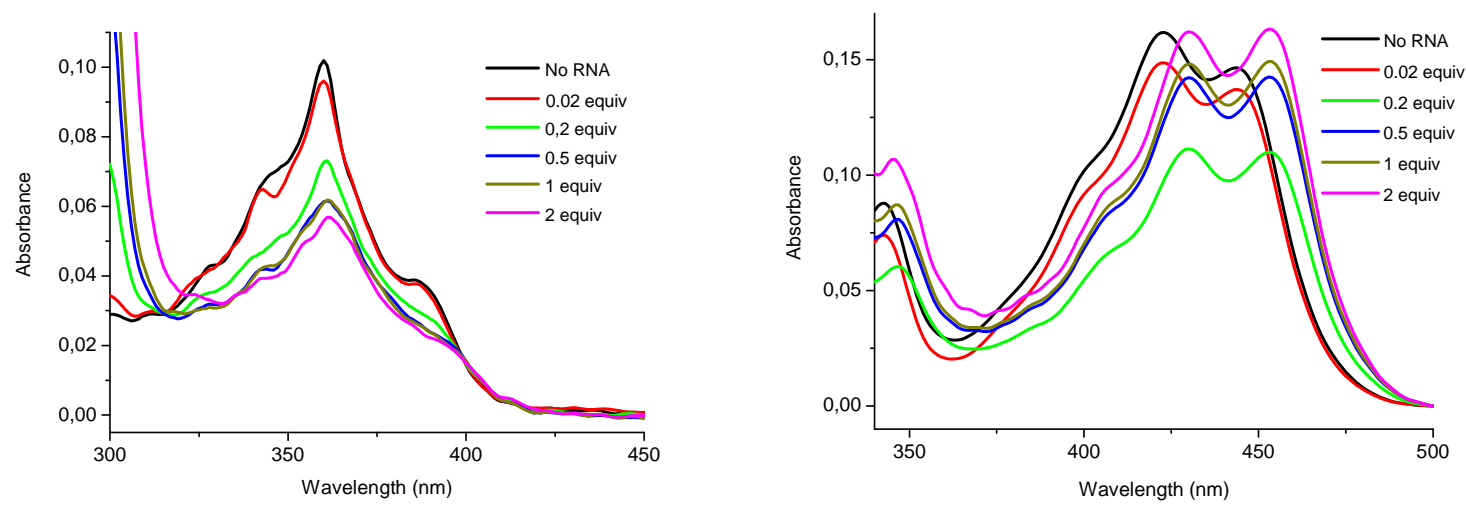

Fig. 3 UV-Vis titration of the Acr1-NeaG4 (left) and Acr2-NeaG4 (right) ligands (50 $\mu \mathrm{M})$ with increasing amounts of wt RNA (0-2 eq) in a $10 \mathrm{mM}$ sodium phosphate buffer, $\mathrm{pH}$ 6.8, containing 100 $\mathrm{mM} \mathrm{NaCl}$ and $0.1 \mathrm{mM} \mathrm{Na}_{2}$ EDTA.

NMR spectroscopy was used to gain an insight into the effect of guanidinylation on the binding mode of acridine-neamine containing ligands. The effect of ligand addition on the imino region of the NMR spectra of wt RNA was studied using Acr1-Nea and Acr1-NeaG4. As shown in Fig. S4 (see the Supporting Information), the addition of Acr1-Nea caused a general line broadening of all signals but no significant changes in the chemical shifts. These effects on the NMR spectra indicate that the ligand binds the RNA with intermediate exchange kinetics, which is consistent with its moderate binding affinity. However, addition of the guanidinylated analogue of this ligand, Acr1-NeaG4, provoked less broadening at the same RNA/ligand ratio as well as some minor changes in the chemical shifts of some imino 
protons of the RNA. This effect was particularly significant for the imino resonance of $\mathrm{G}+1$ ( $\delta: 12.65 \mathrm{ppm}$ ), which was shifted in the RNA-ligand complex ( $\delta: 12.53 \mathrm{ppm})$. Further addition of the ligand caused a pronounced broadening of all signals in the NMR spectra. Taken together, these effects on the NMR spectra and the UV-Vis spectroscopy results lead us to suggest that the heteroaromatic moiety of acridine-guanidinoneamine ligands may intercalate or stack around the bulged adenine. This binding mode is consistent with results reported recently by Varani et al. for the Tau-RNA-mitoxantrone complex. ${ }^{10 \mathrm{c}}$ Moreover, changes in the chemical shifts of the imino resonances in the upper helical region (e.g., G+1 and $U+2$ ) may be a consequence of strong binding of the guanidinoglycoside moiety of Acr1NeaG4 in comparison with that of neamine in Acr1-Nea.

Finally, circular dichroism was used to study the conformation of the RNA-ligand complexes. CD spectra of wt and of the +3 mutant were recorded in the presence of 1 mol eq of the most representative guanidinylated ligands, Acr1-NeaG4 and Acr2-NeaG4. As shown in Fig. 4, the typical spectra of A-form RNA were obtained for wt and +3 sequences alone, with a strong negative band at $211 \mathrm{~nm}$, two small bands at 223 and $234 \mathrm{~nm}$, and a strong positive band at $268 \mathrm{~nm}$; the presence of a shoulder at $280 \mathrm{~nm}$ is a characteristic feature of duplexes capped with a loop structure. ${ }^{22}$ Upon binding of Acr1-NeaG4 or Acr2-NeaG4, the CD spectra of the complexes were essentially superimposable on that of wt RNA (Fig. 4A) which indicates that the conformation of the stem-loop structure had not been substantially altered. However, the effect of the ligands on the conformation of the +3 mutated RNA was more substantial possibly due to the intrinsically lower thermodynamic stability compared with that of wt. As shown in Fig. 4B, the alterations induced by the ligands in duplex CD bands included a decrease in the intensity of the positive band at $234 \mathrm{~nm}$ and a concomitant increase in the ellipticity of the positive band at $268 \mathrm{~nm}$, together with a small wavelength shift (a $3 \mathrm{~nm}$ blueshift for Acr1-Nea/NeaG4 and a $1 \mathrm{~nm}$ red-shift for Acr2-Nea/NeaG4). The overall changes are also consistent with a small binding-induced change in the conformation of the +3 mutant sequence, although typical A-spectra were maintained in all cases, this being important for the recognition of the ligand-stabilized stem-loop by the splicing regulatory machinery. It is particularly interesting to note that ligands with higher binding affinities and stabilizing properties (e.g. Acr2-NeaG4) induced higher alterations in the CD spectra of RNA upon binding. 

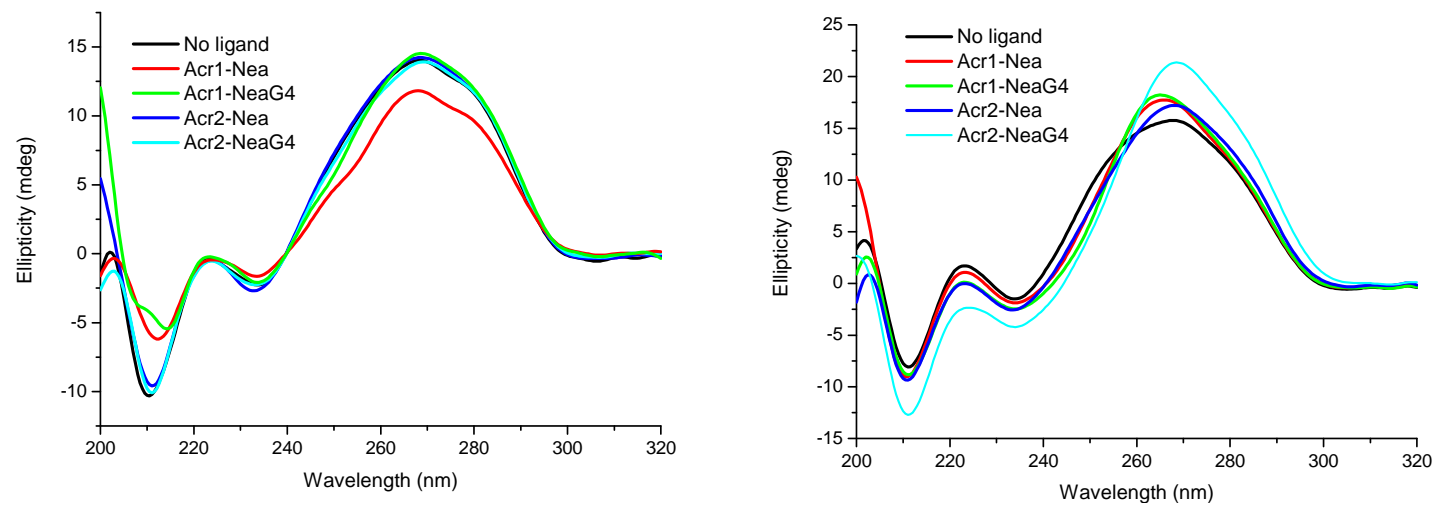

Fig. 4 Overlay of CD spectra for the wt (left) and +3 (right) mutated RNA and its ligand complexes at a [ligand $] /[$ RNA $]$ ratio of 1.0 .

\section{Conclusions}

In summary, we have shown that guanidinylation of the aminoglycoside moiety of ligands combining neamine and acridine strongly influences their RNA-binding properties (affinity, specificity and stabilizing ability). The distance between the two fragments in our modularly assembled ligands is a key parameter since it influences the effect of guanidinylation on these properties, either positively or negatively. For example, guanidinylation has a positive effect on acridine-neamine ligands containing the longest spacer since higher binding affinities for Tau RNA were determined by fluorimetry (e.g. $\mathrm{EC}_{50}=2.4 \mu \mathrm{M}$ for Acr2-NeaG4 vs. $\mathrm{EC}_{50}=$ $5.9 \mu \mathrm{M}$ for Acr2-Nea). However, guanidinylation of the analogous ligand containing the shortest spacer resulted in a reduced binding affinity for Tau RNA (e.g. $\mathrm{EC}_{50}=3.6 \mu \mathrm{M}$ for Acr2-Nea2G4 vs. $\mathrm{EC}_{50}=2.1 \mu \mathrm{M}$ for Acr2-Nea2). The same correlation was observed in the ability of such ligands to stabilize Tau RNA, particularly the +3 and +14 mutated sequences associated with the development of FTDP-17. For example, Acr2-NeaG4 stabilized the +3 mutant by $5.9^{\circ} \mathrm{C}$ whereas Acr2-Nea2G4 only increased the $\mathrm{T}_{\mathrm{m}}$ value by $2.9^{\circ} \mathrm{C}$. Hence, guanidinium modification in ligands with the longest spacer substantially increased the stability of the target RNA $\left(+3.1^{\circ} \mathrm{C}\right)$ whereas the guanidinium-containing derivative with the shortest spacer showed less thermal stabilization $\left(-2.8^{\circ} \mathrm{C}\right)$ than the parent non-guanidinylated ligand. These results might be attributed to the generation of some sterical hindrance by the four guanidinium groups when acridine and guanidinoneamine are closely attached, which may make it difficult for both entities of the ligand to adopt the optimal binding site in RNA. In addition, competition studies performed in the presence of an excess of tRNA revealed that guanidinylation of the aminoglycoside fragment in Tau acridine-neamine ligands has, in 
general, a positive effect on their specificity. Furthermore, CD spectroscopy indicated that guanidinylated ligands do not significantly change the overall structure of the stem-loop RNA, whereas UV-Vis and NMR spectroscopy titration experiments suggested that the heteroaromatic moiety intercalates or stacks, probably near the bulging adenine of the stemloop structure.

It is also important to mention that there was a correlation between the RNA-binding properties of the ligands and the results of dynamic combinatorial chemistry experiments, thereby confirming the usefulness of this methodology for identifying ligands for a particular RNA target. The identification of acridine-guanidinoneamine ligands that bind and stabilize the mutated sequences of Tau exon 10 splicing regulatory element RNA may open up possibilities for the generation of small molecules for the treatment of frontotemporal dementias such as FTDP-17 by restoring the physiological balance of Tau isoforms. Moreover, the guanidinium groups incorporated into such ligands are expected to improve their pharmacological properties, such as permeability through cell membranes, a key issue for conferring drug-like properties to RNA ligands, although this chemical modification does not guarantee their ability to cross the blood-brain barrier. These compounds may also be attractive for studying alternative splicing and its regulation by RNA secondary structures. Current efforts are aimed at improving the affinity and specificity of such Tau RNA ligands by modulating the heteroaromatic and aminoglycoside moieties. 


\section{Experimental Section}

Materials and Methods. Unless otherwise stated, common chemicals and solvents (HPLC grade or reagent grade quality) were purchased from commercial sources and used without further purification. Fmoc-protected amino acids, resins and coupling reagents for solid phase synthesis were obtained from Novabiochem, Bachem or Iris Biotech. RNA, biotin and fluoresceine phosphoramidites, solid-supports, reagents and solvents for oligoribonucleotide synthesis were purchased from Glen Research or Link Technologies.

RNase-free reagents, solutions and materials were used when manipulating deprotected oligoribonucleotides. RNase-free water was obtained directly from a Milli-Q system equipped with a 5000-Da ultrafiltration cartridge.

Solid-phase syntheses were performed manually in a polypropylene syringe fitted with a polyethylene disc (building blocks and peptides), or using the ABI3400 automatic DNA synthesizer from Applied Biosystems (oligonucleotides).

Thin-layer chromatography analyses (TLC) were conducted on aluminium plates coated with a $0.2 \mathrm{~mm}$ thick layer of silica gel $60 \mathrm{~F}_{254}$ (Merck). Purification by flash column chromatography was carried out using silica gel 60 (230-400 mesh).

Reversed-phase high-performance liquid chromatography (HPLC) analyses were carried out on Kromasil or Nucleosil $\mathrm{C}_{18}$ columns $(250 \times 4.6 \mathrm{~mm}, 10$ or $5 \mu \mathrm{m}$, flow rate: $1 \mathrm{~mL} / \mathrm{min})$, using linear gradients of $0.045 \%$ TFA in $\mathrm{H}_{2} \mathrm{O}$ and $0.036 \%$ TFA in ACN for peptides, monomers and ligands, and $0.1 \mathrm{M}$ aqueous $\mathrm{NH}_{4} \mathrm{HCO}_{3}$, and a 1:1 mixture of $0.1 \mathrm{M}$ aqueous $\mathrm{NH}_{4} \mathrm{HCO}_{3}$ and ACN for RNA. In some cases, purification was carried out using the same analytical column. A [Vydac $\mathrm{C}_{18}$ ]-filled glass column $(22 \times 2 \mathrm{~cm}, 15-20 \mu \mathrm{m}, 300 \AA)$ was used for medium pressure liquid chromatography (MPLC), using aqueous and ACN solutions containing $0.05 \%$ TFA (flow rate: $2-3 \mathrm{~mL} / \mathrm{min}$ ). Elution was carried out by connecting a piston pump to the mixing chamber of a gradient-forming device and to the top of the glass column. The mixing chamber of the gradient-forming device was the flask containing solvent $\mathrm{A}$, which was connected through a stopcock to the flask containing solvent $\mathrm{B}$. The bottom of the preparative column was connected to an automatic fraction collector through a UV/Vis detector which was also connected to a chart recorder using the appropriate ports. Equilibration of the column was carried out with $200 \mathrm{~mL}$ of solvent $\mathrm{A}$, and $600 \mathrm{~mL}$ of each mobile phase was introduced in the appropriate compartments of the gradient-forming device.

NMR spectra were recorded at $25^{\circ} \mathrm{C}$ on Varian spectrometers (400 or $500 \mathrm{MHz}$ ) using deuterated solvents. Tetramethylsilane (TMS) was used as an internal reference $(0 \mathrm{ppm})$ for ${ }^{1} \mathrm{H}$ spectra recorded in $\mathrm{CDCl}_{3}$ and the residual signal of the solvent $(77.16 \mathrm{ppm})$ for ${ }^{13} \mathrm{C}$ 
spectra. For $\mathrm{CD}_{3} \mathrm{OD}$ or $\mathrm{D}_{2} \mathrm{O}$, the residual signal of the solvent was used as a reference. Chemical shifts are reported in part per million (ppm) in the $\delta$ scale, coupling constants in $\mathrm{Hz}$ and multiplicity as follows: s (singlet), d (doublet), $\mathrm{t}$ (triplet), q (quadruplet), qt (quintuplet), $\mathrm{m}$ (multiplet), dd (doublet of doublets), td (doublet of triplets), ddd (doublet of doublet of doublets), br (broad signal).

Matrix-assisted laser desorption ionization time-of-flight (MALDI-TOF) mass spectra were recorded on a Voyager-DE ${ }^{\mathrm{TM}} \mathrm{RP}$ spectrometer (Applied Biosystems) both in positive (2,4dihidroxybenzoic acid matrix) or negative mode (2,4,6-trihidroxyacetophenone matrix with ammonium citrate as an additive). Electrospray ionization mass spectra (ESI-MS) were recorded on a Micromass ZQ instrument with single quadrupole detector coupled to an HPLC, and high-resolution (HR) ESI-MS on an Agilent 1100 LC/MS-TOF instrument.

General procedure for the RNA-templated DCC experiments. DCC experiments were carried out as previously described. ${ }^{8}$ Briefly, $6 \mathrm{nmol}$ of biotinylated wt RNA were annealed in $240 \mu \mathrm{L}$ of buffer (50 mM Tris-HCl, pH 7.7, $100 \mathrm{mM} \mathrm{NaCl}$ and $0.1 \mathrm{mM} \mathrm{Na}_{2}$ EDTA) by heating to $90{ }^{\circ} \mathrm{C}$ for $5 \mathrm{~min}$ and then slowly cooling to room temperature. After overnight incubation at RT, the solutions were stored at $4{ }^{\circ} \mathrm{C}$. Then, annealed biotinylated RNA was added to an Eppendorf tube containing the quantified (Ellman's test) thiol building blocks, and the resulting mixture left to stand at RT under air without stirring. At the desired time, the disulfide exchange was stopped by the addition of $45-70 \mu \mathrm{L}$ of $0.1 \%$ TFA solution in water (final $\mathrm{pH} \sim 5-6$ ).

The biotinylated RNA and the binding ligands were isolated with streptavidin-coated magnetic beads (Biomag Streptavidin, $5 \mathrm{mg} \mathrm{mL}^{-1}$ suspension, Qiagen). A magnet was used in all washing procedures to retain the beads in the tube while the supernatant was pipetted off. First, the beads ( $500 \mu \mathrm{L}$ of suspension for each DCL aliquot) were separated from the commercial buffer solution and washed with an acidic buffer $(3 \times 500 \mu \mathrm{L}$ of $50 \mathrm{mM}$ Tris- $\mathrm{HCl}$, pH 5.8, $100 \mathrm{mM} \mathrm{NaCl}$ and $0.1 \mathrm{mM} \mathrm{Na} 2$ EDTA). DCL aliquots were added to the washed beads and incubated at room temperature. After $20 \mathrm{~min}$, the beads were retained in the vessel using the magnet and the supernatant solution was pipetted off again. Then, the beads were treated to remove the non-interacting ligands and building blocks ( 3 x $200 \mu \mathrm{L}$ of $50 \mathrm{mM}$ Tris$\mathrm{HCl}, \mathrm{pH} 5.8,100 \mathrm{mM} \mathrm{NaCl}$ and $0.1 \mathrm{mM} \mathrm{Na}_{2}$ EDTA). Finally, the beads were washed with a hot solution of $0.1 \%$ TFA in $\mathrm{H}_{2} \mathrm{O}$ in order to liberate RNA-binding ligands ( 3 x $200 \mu \mathrm{L}$, incubation at $90^{\circ} \mathrm{C}$ for $10 \mathrm{~min}$ ). The solutions were combined and evaporated in a Speed-Vac. The final residue was dissolved in $0.1 \%$ TFA in $\mathrm{H}_{2} \mathrm{O}$ and analysed by UV-MS HPLC. 
Elution was performed on a GraceSmart $\mathrm{C}_{18}$ column $(150 \times 2.1 \mathrm{~mm}, 5 \mu \mathrm{m}$, flow rate: $0.25 \mathrm{~mL}$ $\mathrm{min}^{-1}$ ) with linear gradients of $\mathrm{H}_{2} \mathrm{O}$ and $\mathrm{ACN}$ containing both solvents either $0.1 \%$ formic acid or $0.1 \%$ formic acid and $0.01 \%$ TFA to avoid the overlapping of some peaks and to allow a more accurate integration. All peak areas of the HPLC traces were integrated and normalized taking into account the extinction coefficient of each compound at the detection wavelength $(260 \mathrm{~nm}){ }^{8}$

\section{Synthesis of the guanidinylated neamine monomer NeaG4-SS ${ }^{t}$ Bu. $(\text { Boc })_{8} N e a G 4$ :}

Neamine thiol monomer (Nea) (50 mg, $0.114 \mathrm{mmol}$ ) was dissolved in a 5:3 mixture of $\mathrm{MeOH} / \mathrm{CHCl}_{3}$ 5:3 (5 mL). Then, 1,3-di-Boc-2-(trifluoromethylsulfonyl)guanidine (892 mg, $2.28 \mathrm{mmol})$, dithiotreitol $(90 \mathrm{mg}, 0.59 \mathrm{mmol})$ and triethylamine $(640 \mu \mathrm{L}, 13.68 \mathrm{mmol})$ were added sequentially. After stirring for 4 days at RT under Ar, the reaction mixture was diluted with $\mathrm{CHCl}_{3}(100 \mathrm{~mL})$ and washed with a $0.1 \mathrm{M}$ aqueous solution of citric acid $(2 \times 50 \mathrm{~mL})$ and with brine $(50 \mathrm{~mL})$. The organic phase was taken up and dried over anhydrous $\mathrm{MgSO}_{4}$, filtered and concentrated in vacuo to dryness. After flash column chromatography (gradient: $0-4 \% \mathrm{MeOH}$ in DCM), the desired product was obtained as white solid (30 mg, $18 \%$ ). $\mathrm{R}_{\mathrm{f}}(4$ \% MeOH en DCM): 0.61; ${ }^{1} \mathrm{H}$ NMR (400 MHz, CD $\left.3 \mathrm{OD}\right) \delta(\mathrm{ppm}): 5.67(1 \mathrm{H}, \mathrm{d}, J=4), 4.54$ (1H, ddd, $\left.J=11, J^{\prime}=6.8, J^{\prime \prime}=4.4\right), 4.36\left(1 \mathrm{H}, \mathrm{dd}, J=10.6, J^{\prime}=4\right), 4.12(1 \mathrm{H}, \mathrm{ddd}, J=13.2$, $\left.J^{\prime}=7.4, J^{\prime \prime}=4.8\right), 3.95\left(1 \mathrm{H}, \mathrm{dt}, J=8.4, J^{\prime}=6.4\right), 3.83\left(1 \mathrm{H}, \mathrm{td}, J=9.2, J^{\prime}=2.4\right), 3.78(1 \mathrm{H}, \mathrm{td}$, $\left.J=9.2, J^{\prime}=2.4\right), 3.70(1 \mathrm{H}, \mathrm{m}), 3.55\left(1 \mathrm{H}, \mathrm{dd}, J=10.8, J^{\prime}=9\right), 3.47\left(1 \mathrm{H}, \mathrm{dt}, J=11.2, J^{\prime}=5.8\right), 3.40$ $(2 \mathrm{H}, \mathrm{m}), 3.26(1 \mathrm{H}, \mathrm{t}, J=9.2), 2.64\left(1 \mathrm{H}, \mathrm{dd}, J=6.8, J^{\prime}=1.2\right), 2.48(2 \mathrm{H}, \mathrm{t}, J=7.2), 2.24(1 \mathrm{H}, \mathrm{dt}$, $\left.J=12.4, J^{\prime}=4.4\right), 1.45-1.70(79 \mathrm{H}, \mathrm{m}), 1.35(2 \mathrm{H}, \mathrm{q}, J=7.4) ;{ }^{13} \mathrm{C} \mathrm{NMR}\left(100 \mathrm{MHz}, \mathrm{CD}_{3} \mathrm{OD}\right) \delta$ (ppm): 164.7, 164.5, 164.4, 164.3, 158.3, 158.0, 157.6, 157.6, 154.7, 154.5, 154.2, 154.0, 98.0, 87.7, 84.8, 84.8, 84.7, 84.6, 80.6, 80.6, 80.6, 80.5, 78.4, 77.0, 74.9, 73.4, 73.0, 71.9, 55.4, 52.2, 50.3, 44.3 35.5, 35.4, 31.2, 29.4, 28.8-28.3, 26.8, 24.9; ESI-MS, positive mode: $m / z 1408.0$ (calcd mass for $\mathrm{C}_{62} \mathrm{H}_{111} \mathrm{~N}_{12} \mathrm{O}_{22} \mathrm{~S}[\mathrm{M}+\mathrm{H}]^{+}:$1407.77).

(Boc) ${ }_{8} N \boldsymbol{N e G} 4-S_{S} \boldsymbol{B} \boldsymbol{B u}$ : A solution of methoxycarbonylsulfenyl chloride $(2.8 \mu \mathrm{L}, 31.2 \mu \mathrm{mol})$ and $\mathrm{NEt}_{3}(4.3 \mu \mathrm{L}, 31.2 \mu \mathrm{mol})$ in $\mathrm{MeOH}(0.3 \mathrm{~mL})$ was added dropwise and under Ar to a solution of (Boc) $)_{8}$ NeaG4 $(22 \mathrm{mg}, 15.6 \mu \mathrm{mol})$ in a 1:1 mixture of $\mathrm{MeOH} / \mathrm{CHCl}_{3}(0.5 \mathrm{~mL})$ at 0 ${ }^{\circ} \mathrm{C}$. The reaction mixture was continuously stirred at $0{ }^{\circ} \mathrm{C}$ under $\mathrm{Ar}$ and additional aliquots of methoxycarbonylsulfenyl chloride $(2.8 \mu \mathrm{L}, 31.2 \mu \mathrm{mol})$ and $\mathrm{NEt}_{3}(4.3 \mu \mathrm{L}, 31.2 \mu \mathrm{mol})$ in $\mathrm{MeOH}(0.3 \mathrm{~mL})$ were added until no starting product was detected by MALDI-TOF MS analysis. Then, the mixture was concentrated in vacuo. The remaining crude was dissolved in $\mathrm{MeOH}(0.3 \mathrm{~mL})$ and the solution was added, dropwise and under Ar, to a solution of 2- 
methyl-2-propanethiol $(18 \mu \mathrm{L}, 0.156 \mathrm{mmol})$ and $\mathrm{NEt}_{3}(21 \mu \mathrm{L}, 0.156 \mathrm{mmol})$ in $\mathrm{MeOH}(0.5$ $\mathrm{mL}$ ). After stirring for $1 \mathrm{~h}$ at $\mathrm{RT}$ under Ar, the solvent was evaporated in vacuo and the residue was dissolved in DCM $(10 \mathrm{~mL})$. The organic phase was washed with $10 \%$ aqueous citric acid solution $(3 \times 10 \mathrm{~mL})$ and brine $(10 \mathrm{~mL})$, dried over anhydrous $\mathrm{MgSO}_{4}$ and filtered, and the solvent was removed in vacuo. Purification by silica gel flash column chromatography (gradient: $0-2 \%$ of $\mathrm{MeOH}$ in DCM) afforded the desired product as a white solid (8 mg, $35 \%)$. $\mathrm{R}_{\mathrm{f}}\left(2 \% \mathrm{MeOH}\right.$ in DCM): 0.19; ${ }^{1} \mathrm{H}-\mathrm{NMR}\left(400 \mathrm{MHz}, \mathrm{CDCl}_{3}\right) \delta(\mathrm{ppm})$ : $11.63(1 \mathrm{H}, \mathrm{s}), 11.52(1 \mathrm{H}, \mathrm{s}), 11.42(1 \mathrm{H}, \mathrm{s}), 11.37(1 \mathrm{H}, \mathrm{s}), 8.85(1 \mathrm{H}$, br s $), 8.51(1 \mathrm{H}, \mathrm{br} \mathrm{t}$, $J=5.6), 8.46(1 \mathrm{H}$, br s), $8.17(1 \mathrm{H}, \mathrm{d}, J=8.4), 7.53(1 \mathrm{H}, \mathrm{d}, J=8.4), 7.37(1 \mathrm{H}, \mathrm{d}, J=9.2), 7.12$ $(1 \mathrm{H}, \mathrm{m}), 5.54(1 \mathrm{H}, \mathrm{d}, J=3.6), 4.40(2 \mathrm{H}, \mathrm{m}), 4.20(1 \mathrm{H}, \mathrm{m}), 3.98(2 \mathrm{H}, \mathrm{m}), 3.77(1 \mathrm{H}, \mathrm{t}, J=10.0)$, 3.67-3.54 (4H, m), 3.47 (2H, m), $3.31(2 \mathrm{H}, \mathrm{m}), 2.66$ (1H, t, $J=7.6), 2.34$ (1H, dt, $J=13.2$, $\left.J^{\prime}=4.4\right), 1.62-1.37(90 \mathrm{H}, \mathrm{m})$; ESI-MS, positive mode: $\mathrm{m} / z$ 1495.9 [M+H] ${ }^{+}$; MALDI-TOF-MS, positive mode: $m / z 1496.1$ (calcd mass for $\mathrm{C}_{66} \mathrm{H}_{119} \mathrm{~N}_{12} \mathrm{O}_{22} \mathrm{~S}_{2}[\mathrm{M}+\mathrm{H}]^{+}: 1495.80$ ).

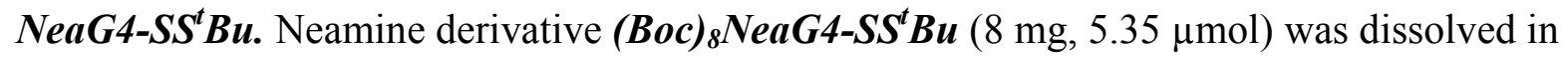
a TFA/DCM mixture $(2 \mathrm{~mL}, 1: 1)$ containing $2.5 \%$ of TIS, and the mixture was stirred at RT for $2 \mathrm{~h}$. Then, the solution was diluted with toluene $(3 \mathrm{~mL})$ and evaporated in vacuo. The residue was dissolved in Milli-Q $\mathrm{H}_{2} \mathrm{O}(10 \mathrm{~mL})$ and the aqueous phase was washed with DCM $(2 \times 10 \mathrm{~mL})$, diethyl ether $(10 \mathrm{~mL})$ and lyophilized to provide a white solid. Purification was carried out by MPLC eluting with a gradient from 0 to $100 \%$ of B (A: $0.05 \%$ TFA in $\mathrm{H}_{2} \mathrm{O}$, B: $0.05 \%$ TFA in $\mathrm{H}_{2} \mathrm{O} / \mathrm{ACN}$ 65:35, $600 \mathrm{~mL}$ each solvent). Pure fractions by ESI-MS HPLC (5 min isocratic elution with A and linear gradient from 0 to $70 \% \mathrm{~B}$ in $25 \mathrm{~min}$; A: $0.1 \%$ formic acid in $\mathrm{H}_{2} \mathrm{O}$ and $\mathrm{B}: 0.1 \%$ formic acid in $\mathrm{ACN} ; \mathrm{R}_{\mathrm{t}}=13.5 \mathrm{~min}$ ) were combined and lyophilized, providing the TFA salt of the desired product NeaG4-SS ${ }^{\mathbf{B}} \mathbf{B u}$ as a white foam (0.54 $\mu$ mol, $12 \%$ ). ESI-MS, positive mode: $m / z 695.43$ (calcd mass for $\mathrm{C}_{26} \mathrm{H}_{55} \mathrm{~N}_{12} \mathrm{O}_{6} \mathrm{~S}_{2}$ $[\mathrm{M}+\mathrm{H}]^{+}:$695.38), $m / z 348.14$ (calcd mass for $\mathrm{C}_{26} \mathrm{H}_{56} \mathrm{~N}_{12} \mathrm{O}_{6} \mathrm{~S}_{2}[\mathrm{M}+2 \mathrm{H}]^{2+}: 348.19$ ); MALDITOF-MS, positive mode: $\mathrm{m} / z 695.38[\mathrm{M}+\mathrm{H}]^{+}$).

\section{Synthesis of the guanidinylated ligands. $\mathrm{N}$-(3-Acrylamidopropyl)acridine-9-carboxamide:}

$\mathrm{N}$-(3-Aminopropyl)acridine-9-carboxamide ${ }^{8}(300 \mathrm{mg}, 0.76 \mathrm{mmol})$ and $\mathrm{NaHCO}_{3}(256 \mathrm{mg}$, $3.05 \mathrm{mmol})$ were dissolved in a 1:1 mixture of $\mathrm{H}_{2} \mathrm{O} /$ dioxane $(30 \mathrm{~mL})$ and cooled to $0{ }^{\circ} \mathrm{C}$. Then, a solution of acryloyl chloride $(230 \mu \mathrm{L}, 2.28 \mathrm{mmol})$ in dioxane $(2 \mathrm{~mL})$ was added dropwise and the resulting reaction mixture was stirred at $0{ }^{\circ} \mathrm{C}$ for $20 \mathrm{~min}$. Again, acryloyl chloride $(230 \mu \mathrm{L}, 2.28 \mathrm{mmol})$ in dioxane $(2 \mathrm{~mL})$ and $\mathrm{NaHCO}_{3}(200 \mathrm{mg}, 2.38 \mathrm{mmol})$ were added and the mixture was stirred at $0^{\circ} \mathrm{C}$ for additional $20 \mathrm{~min}$, After evaporation in vacuo, 
purification by silica gel flash column chromatography (gradient: $0-3 \%$ of $\mathrm{MeOH}$ in DCM) afforded the desired product (57 mg, $22 \%)$. $\mathrm{R}_{\mathrm{f}}\left(10 \% \mathrm{MeOH}\right.$ en DCM): 0.51; ${ }^{1} \mathrm{H}-\mathrm{NMR}(400$ $\left.\mathrm{MHz}, \mathrm{CD}_{3} \mathrm{OD}\right) \delta$ (ppm): $8.20(2 \mathrm{H}, \mathrm{d}, J=8.8), 8.10(2 \mathrm{H}, \mathrm{d}, J=8.8), 7.89$ (2H, ddd, $J=8.8$, $\left.J^{\prime}=6.8, J^{\prime \prime}=1.2\right), 7.69\left(2 \mathrm{H}, \mathrm{ddd}, J=8.8, J^{\prime}=6.8, J^{\prime}=1.2\right), 6.28(1 \mathrm{H}, \mathrm{dd}, J=17.2, J=9.0), 6.22$ $(1 \mathrm{H}, \mathrm{dd}, J=17.2, J=3.0), 5.67(1 \mathrm{H}, \mathrm{dd}, J=9.0, J=3.0), 3.69$ (2H, t, $J=6.8), 3.46(2 \mathrm{H}, \mathrm{t}, J=6.8)$, $2.00(2 \mathrm{H}, \mathrm{q}, J=6.8) ;{ }^{13} \mathrm{C}-\mathrm{NMR}\left(100 \mathrm{MHz}, \mathrm{CD}_{3} \mathrm{OD}\right) \delta$ (ppm): 169.3, 168.4, 149.6, 143.8, 132.3, 132.0, 129.6, 128.3, 126.8, 126.6, 123.7, 38.7, 38.2, 30.3; ESI-MS, positive mode: $\mathrm{m} / \mathrm{z}$ 334.1 (calcd mass for $\mathrm{C}_{20} \mathrm{H}_{20} \mathrm{~N}_{3} \mathrm{O}_{2}[\mathrm{M}+\mathrm{H}]^{+}: 334.15$ ).

Acr1-NeaG4: $N$-(3-acrylamidopropyl)acridine-9-carboxamide (10 mg, $30 \mu \mathrm{mol})$, (Boc) $)_{8}$ NeaG4 (50 mg, $\left.36 \mu \mathrm{mol}\right)$ and $\mathrm{NaH}(3.6 \mathrm{mg}, 90 \mu \mathrm{mol}, 60 \%$ dispersion in mineral oil) were dissolved in anhydrous DMF ( $5 \mathrm{~mL})$ and stirred at RT for $4 \mathrm{~h}$ under Ar. Then, the mixture was diluted with water $(1 \mathrm{~mL})$ and evaporated to dryness. After several coevaporations from acetonitrile, purification by flash chromatography (gradient: $0-10 \%$ of $\mathrm{MeOH}$ in DCM) afforded the desired Boc-protected intermediate (42 mg crude).

The product was dissolved in a 1:1 mixture of TFA/DCM $(2 \mathrm{~mL})$ and TIS $(80 \mu \mathrm{L}, 390 \mu \mathrm{mol})$ and ethanedithiol $(80 \mu \mathrm{L}, 990 \mu \mathrm{mol})$ were added. After stirring at RT for $3 \mathrm{~h}$ under Ar, the mixture was diluted with toluene $(2 \mathrm{~mL})$ and evaporated in vacuo. After two co-evaporations from toluene, the residue was dissolved in Milli-Q $\mathrm{H}_{2} \mathrm{O}(20 \mathrm{~mL})$ and the aqueous phase was washed with DCM (2 x $20 \mathrm{~mL})$, diethyl ether $(20 \mathrm{~mL})$ and lyophilized to provide a white solid. Purification was carried out by MPLC eluting with a gradient from 0 to $100 \%$ of B (A: $0.05 \%$ TFA in $\mathrm{H}_{2} \mathrm{O} / \mathrm{ACN}$ 95:5, B: $0.05 \%$ TFA in $\mathrm{H}_{2} \mathrm{O} / \mathrm{ACN}$ 70:30, $600 \mathrm{~mL}$ each solvent). Pure fractions by analytical HPLC (linear gradient from 0 to $50 \%$ B in $30 \mathrm{~min}$; A: $0.045 \%$ TFA in $\mathrm{H}_{2} \mathrm{O}$ and $\mathrm{B}: 0.036 \%$ TFA in $\mathrm{ACN} ; \mathrm{R}_{\mathrm{t}}=19.1 \mathrm{~min}$ ) were combined and lyophilized, providing the TFA salt of the desired product ( $8 \mathrm{mg}, 20 \%) .{ }^{1} \mathrm{H}-\mathrm{NMR}\left(400 \mathrm{MHz}, \mathrm{CD}_{3} \mathrm{OD}\right) \delta$ (ppm): 8.25 (2H, d, $J=8.8), 8.17$ (2H, d, $J=8.4$ ), 7.99 (2H, ddd, $J=8.8, J=6.8, J=1.2), 7.56$ (2H, ddd, $J=8.4, J=6.8, J=1.2), 5.72(1 \mathrm{H}, \mathrm{d}, J=3.6), 3.98(1 \mathrm{H}, \mathrm{m}), 3.71(2 \mathrm{H}, \mathrm{t}, J=6.8), 3.67-$ $3.60(4 \mathrm{H}, \mathrm{m}), 3.56(1 \mathrm{H}, \mathrm{m}), 3.52(2 \mathrm{H}, \mathrm{m}), 3.43-3.35(5 \mathrm{H}, \mathrm{m}), 3.21(2 \mathrm{H}, \mathrm{q}, J=7.2), 2.80(2 \mathrm{H}, \mathrm{t}$, $J=7.2), 2.55(2 \mathrm{H}, \mathrm{t}, J=7.2), 2.53(2 \mathrm{H}, \mathrm{t}, J=7.2), 2.10(1 \mathrm{H}, \mathrm{dt}, J=12.4, J=3.6), 1.98(2 \mathrm{H}, \mathrm{q}$, $J=6.8), 1.67$ (1H, q, $J=12.4), 1.61-1.49(4 \mathrm{H}, \mathrm{m}), 1.42-1.33$ (4H, m); ESI-MS, positive mode: $m / z 471.3$ (calcd mass for $\mathrm{C}_{42} \mathrm{H}_{67} \mathrm{~N}_{15} \mathrm{O}_{8} \mathrm{~S}[\mathrm{M}+2 \mathrm{H}]^{2+}: 470.75$ ); HR ESI-MS, positive mode: $m / z$ 470.7520 (calcd mass for $\mathrm{C}_{42} \mathrm{H}_{67} \mathrm{~N}_{15} \mathrm{O}_{8} \mathrm{~S}[\mathrm{M}+2 \mathrm{H}]^{2+}$ : 470.7509 ), $m / z 314.1715$ (calcd mass for $\left.\mathrm{C}_{42} \mathrm{H}_{68} \mathrm{~N}_{15} \mathrm{O}_{8} \mathrm{~S}[\mathrm{M}+3 \mathrm{H}]^{3+}: 314.1699\right)$.

Acr2-NeaG4: 1,3-di-Boc-2-(trifluoromethylsulfonyl)guanidine (38 mg, $96 \mu \mathrm{mol}$ ) and Acr2Nea ligand ${ }^{8}(3.4 \mathrm{mg}, 2.4 \mu \mathrm{mol})$ were dissolved in a 5:3 mixture of $\mathrm{MeOH} / \mathrm{CHCl}_{3}(1 \mathrm{~mL})$. 
After addition of triethylamine $(80 \mu \mathrm{L}, 576 \mu \mathrm{mol})$, the reaction mixture was stirred for 4 days at RT under Ar. The mixture was concentrated in vacuo and the residue was dissolved in $\operatorname{DCM}(10 \mathrm{~mL})$ and washed with a $0.1 \mathrm{M}$ aqueous solution of citric acid $(2 \times 10 \mathrm{~mL})$ and with brine $(10 \mathrm{~mL})$. The organic phase was taken up and dried over anhydrous $\mathrm{MgSO}_{4}$, filtered and concentrated in vacuo to dryness. Then, the crude was dissolved in a 1:1 mixture of TFA/DCM (1 mL) containing $2.5 \%$ TIS. After stirring at RT for $2 \mathrm{~h}$ under Ar, the mixture was diluted with toluene $(2 \mathrm{~mL})$ and evaporated in vacuo. After two co-evaporations from toluene, the residue was dissolved in Milli-Q $\mathrm{H}_{2} \mathrm{O}(10 \mathrm{~mL})$ and the aqueous phase was washed with DCM (2 x $10 \mathrm{~mL})$, diethyl ether $(10 \mathrm{~mL})$ and lyophilized. The sulfoxide derivative of the product was isolated $(1.35 \mu \mathrm{mol}, 56 \%)$ by reversed-phase HPLC (linear gradient from 10 to $40 \% \mathrm{~B}$ in $30 \mathrm{~min}$; $\mathrm{A}: 0.045 \%$ TFA in $\mathrm{H}_{2} \mathrm{O}$ and $\mathrm{B}: 0.036 \%$ TFA in $\mathrm{ACN}$; $\left.\mathrm{R}_{\mathrm{t}}=15.8 \mathrm{~min}\right) .{ }^{1} \mathrm{H}-\mathrm{NMR}\left(400 \mathrm{MHz}, \mathrm{D}_{2} \mathrm{O}\right) \delta(\mathrm{ppm}): 8.37(1 \mathrm{H}, \mathrm{d}, J=9.2), 7.85(1 \mathrm{H}, \mathrm{d}, J=1.8)$, $7.79(1 \mathrm{H}, \mathrm{d}, J=9.2), 7.73(1 \mathrm{H}, \mathrm{d}, J=2.6), 7.69$ (1H, dd, $\left.J=9.2, J^{\prime}=2.6\right), 7.51$ (1H, dd, $J=9.2$, $\left.J^{\prime}=1.8\right), 5.60(1 \mathrm{H}, \mathrm{d}, J=4.0), 4.20(2 \mathrm{H}, \mathrm{t}, J=6.4), 4.02(3 \mathrm{H}, \mathrm{s}), 3.98(1 \mathrm{H}, \mathrm{m}), 3.62-3.74(4 \mathrm{H}$, m), 3.46-3.59 (8H, m), $3.31(2 \mathrm{H}, \mathrm{t}, J=6.4), 2.78(2 \mathrm{H}, \mathrm{t}, J=7.2), 2.70(2 \mathrm{H}, \mathrm{m}), 2.26(1 \mathrm{H}, \mathrm{m})$, 2.13 (4H, m), 1.65-1.77 (5H, m), 1.40-1.59 (6H, m); ESI-MS, positive mode: $m / z 990.9$ (calcd mass for $\mathrm{C}_{43} \mathrm{H}_{69} \mathrm{ClN}_{15} \mathrm{O}_{8} \mathrm{~S}[\mathrm{M}+\mathrm{H}]^{+}$: 990.49); HR ESI-MS, positive mode: $m / z 503.7464$ (calcd mass for $\mathrm{C}_{43} \mathrm{H}_{70} \mathrm{ClN}_{15} \mathrm{O}_{9} \mathrm{~S}[\mathrm{M}+\mathrm{O}+2 \mathrm{H}]^{2+}:$ 503.7440), $\mathrm{m} / z 336.1667$ (calcd mass for $\left.\mathrm{C}_{43} \mathrm{H}_{71} \mathrm{ClN}_{15} \mathrm{O}_{9} \mathrm{~S}[\mathrm{M}+\mathrm{O}+3 \mathrm{H}]^{3+}: 336.1651\right)$.

Acr2-Nea2 G4: The guanidinylation of Acr2-Nea2 ${ }^{8}$ and the removal of the Boc protecting groups was carried out following the procedure described for the synthesis of Acr2-NeaG4 from Acr2-Nea. After HPLC purification (linear gradient from 10 to $35 \%$ B in 30 min; A: $0.045 \%$ TFA in $\mathrm{H}_{2} \mathrm{O}$ and $\mathrm{B}: 0.036 \%$ TFA in $\left.\mathrm{ACN} ; \mathrm{R}_{\mathrm{t}}=11.4 \mathrm{~min}\right)$, Acr2-Nea2G4 was obtained as a yellow solid (0.9 $\mu$ mol, $25 \%)$. ${ }^{1} \mathrm{H}-\mathrm{NMR}\left(500 \mathrm{MHz}, \mathrm{CD}_{3} \mathrm{OD}\right) \delta(\mathrm{ppm}): 8.25$ $(1 \mathrm{H}, \mathrm{d}, J=9.0), 7.74(1 \mathrm{H}, \mathrm{s}), 7.68(1 \mathrm{H}, \mathrm{d}, J=9.0), 7.60(1 \mathrm{H}, \mathrm{s}), 7.56\left(1 \mathrm{H}, \mathrm{dd}, J=9.0, J^{\prime}=2\right)$, $7.39\left(1 \mathrm{H}, \mathrm{dd}, J=9.0, J^{\prime}=2\right), 5.52(1 \mathrm{H}, \mathrm{d}, J=3.5), 4.06(3 \mathrm{H}, \mathrm{m}), 3.90(3 \mathrm{H}, \mathrm{s}), 3.70(1 \mathrm{H}, \mathrm{m})$, 3.59-3.29 (10H, m), $3.31(1 \mathrm{H}, \mathrm{m}), 3.22(2 \mathrm{H}, \mathrm{t}, J=6.0), 2.69(2 \mathrm{H}, \mathrm{t}, J=6.0), 2.55(2 \mathrm{H}, \mathrm{t}, J=7.0)$, $2.29(2 \mathrm{H}, \mathrm{t}, J=7.0), 2.14(1 \mathrm{H}, \mathrm{m}), 2.03(2 \mathrm{H}, \mathrm{q}, J=6.0), 1.55(1 \mathrm{H}, \mathrm{m})$; MALDI-TOF-MS, positive mode: $\mathrm{m} / \mathrm{z}$ 953.2; ESI-MS, positive mode: $\mathrm{m} / \mathrm{z} 953.10$ (calcd mass for $\mathrm{C}_{38} \mathrm{H}_{59} \mathrm{ClN}_{15} \mathrm{O}_{8} \mathrm{~S}_{2}[\mathrm{M}+\mathrm{H}]^{+}:$952.38).

Synthesis of oligoribonucleotides. Oligoribonucleotides were synthesized using 2'-O-tertbutyldimethylsilyl (TBDMS) protection and following standard procedures (phosphite triester approach). The syntheses (1- $\mu$ mol scale) were performed on an ABI 3400 DNA automatic 
synthesizer according to the manufacturer's synthesis protocol, with some modifications described here. For 5'-O-(dimethoxytrityl)-2'-O-(tert-butyldimethylsilyl (or 2'-O-methyl)-3'$O$-(2-cyanoethyl- $N, N$-diisopropyl)ribonucleoside phosphoramidite monomers, nucleobaseprotecting groups with increased base-sensitivity were used (phenoxyacetyl for adenine, acetyl for cytosine and 4-isopropylphenoxyacetyl for guanine). Benzylthio- $1 H$-tetrazole (80fold excess, $0.3 \mathrm{M}$ in anhydrous $\mathrm{ACN}$ ) was used for the activation of phosphoramidite monomers (10-fold excess, $0.1 \mathrm{M}$ in anhydrous $\mathrm{ACN})$. Biotin- or fluoresceine phosphoramidite were incorporated in the last coupling cycle using tetrazole as activator. Oligoribonucleotides were cleaved from the solid support and deprotected following a stepwise protocol. ${ }^{23}$ First, a fast treatment with concentrated ammonium hydroxide and methylamine cleaved the oligoribonucleotide from the solid support and removed nucleobaseand phosphate-protecting groups. The second step involved treatment with triethylamine tris(hydrofluoride) to remove the 2'-O-TBDMS groups. Reversed-phase HPLC was used both for the analysis and purification of oligoribonucleotides: linear gradient from 0 to $30 \% \mathrm{~B}$ in 30 min for DMT-off sequences (A: $0.1 \mathrm{M}$ aqueous $\mathrm{NH}_{4} \mathrm{HCO}_{3}$ and $\mathrm{B}$ : a 1:1 mixture of $0.1 \mathrm{M}$ aqueous $\mathrm{NH}_{4} \mathrm{HCO}_{3}$ and $\mathrm{ACN}$ ). Characterization was carried out by MALDI-TOF mass spectrometry (negative mode, THAP/CA matrix). Purity was also confirmed by PAGE. In all cases, the ends of the chains were modified with two 2'- $O$-methylribonucleosides (denoted with * label in the sequences, Scheme 1) to increase stability to ribonucleases.

\section{Evaluation of the interaction between RNA and ligands. $A$. $U V$-monitored melting} experiments. Melting curves were recorded by cooling the samples from $90{ }^{\circ} \mathrm{C}$ to $20^{\circ} \mathrm{C}$ at a constant rate of $0.5^{\circ} \mathrm{C} \mathrm{min}^{-1}$ and measuring the absorbance at $260 \mathrm{~nm}$ as a function of temperature. Then, the reverse denaturation curve $\left(20^{\circ} \mathrm{C}\right.$ to $\left.90{ }^{\circ} \mathrm{C}\right)$ was recorded. All experiments were repeated at least three times until coincident $T_{m}$ values were obtained. The error in $\mathrm{T}_{\mathrm{m}}$ values was $\pm 0.2^{\circ} \mathrm{C}$. The solutions were $1 \mu \mathrm{M}$ both in RNA (wt, +3 or +14 ) and in ligands, in $10 \mathrm{mM}$ sodium phosphate buffer $\mathrm{pH} 6.8,100 \mathrm{mM} \mathrm{NaCl}$ and $0.1 \mathrm{mM} \mathrm{Na} \mathrm{EDDTA}_{2}$. B. Circular dichroism. Samples ( $3 \mu \mathrm{M}$ both in RNA and in ligands) were prepared in the same buffer than in UV-monitored melting experiments. Spectra were recorded on a Jasco J720 spectropolarimeter with a thermoregulated cell holder and interfaced with a Neslab RP100 water bath, at $20{ }^{\circ} \mathrm{C}$. All CD spectra were baseline subtracted with a separately acquired buffer spectrum.

C. UV-Vis titration experiments. A $50 \mu \mathrm{M}$ solution of the ligand (Acr1-NeaG4 or Acr2NeaG4) and the corresponding amount of wt RNA $(0,0.02,0.05,0.1,0.5$, and 1 mol equiv) 
was prepared in the previous buffer. The mixture was heated for $5 \mathrm{~min}$ to $90{ }^{\circ} \mathrm{C}$ and left to slowly cool to RT. The absorption spectra were recorded at RT.

D. Fluorescence binding assays. Fluorescence measurements were performed in 1-cm pathlength quartz cells on a QuantaMaster fluorometer (PTI) at $20^{\circ} \mathrm{C}$, with an excitation slit width of $4.0 \mathrm{~nm}$ and an emission slit width of $5.2 \mathrm{~nm}$. Upon excitation at $490 \mathrm{~nm}$, the emission spectrum was recorded over a range between 500 and $550 \mathrm{~nm}$ until no changes in the fluorescence intensity were detected. All binding assays were performed in the melting curves buffer.

For each experiment, the fluorescence spectrum of $120 \mu \mathrm{L}$ buffer solution without RNA or ligand was first taken, to be used as the baseline. Following this buffer blank, the spectrum of a $0.25 \mu \mathrm{M}$ solution of refolded RNA containing fluoresceine $(120 \mu \mathrm{L})$ was recorded, and the baseline blank subtracted. Subsequent aliquots of $1 \mu \mathrm{L}$ of an aqueous ligand solution (increasing in concentration from 0 to $0.75 \mathrm{mM}, 0.0005-3000$ mol equiv, depending on the ligand affinity) were added to the solution containing RNA, and the fluorescence spectrum was recorded after addition of each aliquot until the fluoresceine fluorescence signal at 517 $\mathrm{nm}$ reached saturation (typically 5-10 $\mathrm{min}$ ). Over the entire range of ligand concentrations, the emission maxima varied less than $1 \mathrm{~nm}$. The total volume of the sample never changed more than $20 \%$. The full titration was repeated in the absence of labelled RNA to correct for the presence of the ligand's fluorescence. These spectra were subtracted from each corresponding point of the labelled RNA titrations, and the resulting fluorescence intensity was corrected for dilution $\left(\mathrm{F} * \mathrm{~V} / \mathrm{V}_{0}\right)$.

The emission fluorescence at $517 \mathrm{~nm}$ was normalized by dividing the difference between the observed fluorescence, $F$, and the initial fluorescence, $F_{0}$, by the difference between the final fluorescence, $F_{f}$, and the initial fluorescence, $F_{0}$. This normalized fluorescence intensity was plotted as a function of the logarithm of the total ligand concentration. Finally, nonlinear regression using a sigmoidal dose-response curve was performed with the software package GraphPad Prism 4 (GraphPad Software, San Diego, CA) to calculate the $\mathrm{EC}_{50}$ values.

Experimental errors were less than or equal to $\pm 25 \%$ of each value.

For competitive experiments, a tRNA from baker's yeast (S. cerevisiae) was purchased from Sigma. Stock solutions of tRNA ${ }^{\text {mix }}$ were quantified using an average extinction coefficient of $9.640 \mathrm{~cm}^{-1}$ per base. ${ }^{19 \mathrm{~b}}$ The fluorescence binding assays were carried out as described above with the exception that a 30-fold excess (base) of the tRNA ${ }^{\text {mix }}$ was added to the refolded fluoresceine-labelled RNA (or to the buffer for the titration without target RNA). 
F. NMR Spectroscopy of RNA-ligand complexes. NMR spectra were acquired in a Bruker Advance spectrometer operating at $600 \mathrm{MHz}$ and equipped with a cryoprobe. Samples of the complexes were prepared by mixing the appropriate amounts of RNA and ligand and performing an annealing protocol consisting of heating to $90^{\circ} \mathrm{C}$ for $3 \mathrm{~min}$, followed by snap cooling on ice for $20 \mathrm{~min}$. Samples were dissolved in a $10 \mathrm{mM}$ sodium phosphate, $\mathrm{pH}$ 6.8, in a 9:1 $\mathrm{H}_{2} \mathrm{O} / \mathrm{D}_{2} \mathrm{O}$ mixture and NMR spectra were recorded at $5^{\circ} \mathrm{C}$ to reduce the exchange with water. Water suppression was achieved by using an excitation sculpting sequence (zgesgp).

\section{Acknowledgements}

This work was supported by funds from the Spanish Ministerio de Ciencia e Innovación (grant CTQ2010-21567-C02-01, and the project RNAREG, grant CSD2009-00080, funded under the programme CONSOLIDER INGENIO 2010), the Generalitat de Catalunya (2009SGR-208 and the Xarxa de Referència de Biotecnologia) and the Programa d'Intensificació de la Recerca (Universitat de Barcelona). Paula López-Senín received a fellowship from the Ministerio de Educación y Ciencia and Gerard Artigas from the Universitat de Barcelona. We thank Dr. Margarida Gairí from the Barcelona Scientific Park for NMR technical support.

\section{Notes and references}

1 a) J. R. Thomas and P. J. Hergenrother, Chem. Rev. 2008, 108, 1171; b) F. Aboul-ela, Future Med. Chem. 2010, 2, 93; c) L. Guan and M. D. Disney, ACS Chem. Biol. 2012, 7, 73. 2 a) E. Buratti and F. E. Baralle, Mol. Cell. Biol. 2004, 24, 10505; b) N. N. Singh, R. N. Singh and E. J. Androphy, Nucleic Acids Res. 2007, 35, 371; c) M. Maiti, K. Nauwelaerts and P. Herdewijn, Bioorg. Med. Chem. Lett. 2012, 22, 1709.

3 a) J. Gallego and G. Varani, Acc. Chem. Res. 2001, 34, 836; b) Y. Tor, ChemBioChem 2003, 4, 998; c) B. Carlson, O. M. Stephens and P. A. Beal, Biopolymers 2003, 70, 86; d) N. Foloppe, N.Matassova and F. Aboul-ela, Drug Discov. Today 2006, 11, 1019.

4 a) T. Xia, Curr. Opin. Chem. Biol. 2008, 12, 604; b) J. Lu, B. M. Kadakkuzha, L.

Zhao, M. Fan, X. Qi and T. Xia, Biochemistry 2011, 50, 5042. 
a) F. Saczewski and L. Balewski, Expert Opin. Ther. Patents 2009, 19, 1417; b) D. I. Bryson, W. Zhang, P. M. McLendon, T. M. Reineke and W. L. Santos, ACS Chem. Biol. $2012,7,210$.

6 a) W. K. C. Park, M. Auer, H. Jaksche and C. H. Wong, J. Am. Chem. Soc. 1996, 118, 10150; b) E. E. Swayze, E. A. Jefferson, K. A. Sannes-Lowery, L. B. Blyn, L. M. Risen, S. Arakawa, S. A. Osgood, S. A. Hofstadler and R. H. Griffey, J. Med. Chem. 2002, 45, 3816; c) B. D. Gooch and P. A. Beal, J. Am. Chem. Soc. 2004, 126, 10603; d) B. R. McNaughton, P. C. Gareiss and B. L. Miller, J. Am. Chem. Soc. 2007, 129, 11306; e) J. L. Childs-Disney, P. B. Tsitovich and M. D. Disney, ChemBioChem, 2011, 12, 2143; f) R. Moumné, M. Catala, V. Larue, L. Micouin and C. Tisné, Biochimie, 2012, 94, 1607.

7 a) P. T. Corbett, J. Leclaire, L. Vial, K. R.West, J.-L. Wietor, J. K. M. Sanders and S. Otto, Chem. Rev. 2006, 106, 3652; b) Dynamic Combinatorial Chemistry: In Drug Discovery, Bioorganic Chemistry, and Materials Science, (Ed. B. Miller), John Wiley \& Sons, Inc., Hoboken, N. J., 2010; c) C. R. Sherman Durai and M. M. Harding. Aust. J. Chem. 2011, 64, 671.

8 P. López-Senín, I. Gómez-Pinto, A. Grandas and V. Marchán, Chem. Eur. J. 2011, 17, 1946.

9 a) L. Varani, M. Hasegawa, M. G. Spillantini, M. J. Smith, J. R. Murrell, B. Ghetti, A. Klug, M. Goedert and G. Varani, Proc. Nat. Acad. Sci. U. S. A. 1999, 96, 8229; b) C. P. Donahue, C. Muratore, J. Y. Wu, K. S. Kosik and M. S. Wolfe, J. Biol. Chem. 2006, 281, 23302.

10 a) L. Varani, M. G. Spillantini, M. Goedert and G. Varani, Nucleic Acids Res. 2000, 28, 710; b) C. P. Donahue, J. Ni, E. Rozners, M. A. Glicksman and M. S. Wolfe, J. Biomol. Screening 2007, 12, 789; c) S. Zheng, Y. Chen, C. P. Donahue, M. S. Wolfe and G. Varani, ACS Chem. Biol., 2009, 16, 557; d) Y. Liu, E. Peacey, J. Dickson, C. P. Donahue, S. Zheng, G. Varani and M. S. Wolfe, J. Med. Chem. 2009, 52, 6523.

11 a) F. Liu and G. Cheng-Xin, Mol. Degener. 2008, 3:8; b) M. S. Wolfe, J. Biol. Chem. 2009, 284, 6021.

12 P. López-Senín, Ph.D. Thesis, University of Barcelona, 2010.

13 N. W. Luedtke, T. J. Baker, M. Goodman and Y. Tor, J. Am. Chem. Soc. 2000, 122, 12035.

14 D. W. Staple, V. Venditti, N. Niccolai, L. Elson-Schwab, Y. Tor and S. E. Butcher. ChemBioChem, 2008, 9, 93.

15 N. W. Luedtke, P. Carmichael and Y. Tor, J. Am. Chem. Soc. 2003, 125, 12374. 
16 T. K. Baker, N. W. Luedtke and Y. Tor, J. Org. Chem. 2000, 65, 9054.

17 P. C. Gareiss, K. Sobczak, B. R. McNaughton, P. B. Palde, C. A. Thornton and B. L. Miller. J. Am. Chem. Soc. 2008, 130, 16254.

18 a) B. Llano-Sotelo and C. S. Chow, Bioorg. Med. Chem. Lett. 1999, 9, 213; b) J. R. Thomas, X. Liu and P. J. Hergenrother, Biochemistry 2006, 45, 10928.

19 a) P. C. Gareiss, K. Sobczak, B. R. McNaughton, P. B. Palde, C. A. Thornton and B. L. Miller, J. Am. Chem. Soc. 2008, 130, 16254; b) N. W. Luedtke, Q. Liu and Y. Tor, Biochemistry 2003, 42, 11391; c) S. J. Lee, S. Hyun, J. S. Kieft and J. Yu, J. Am. Chem. Soc. 2009, 131, 2224.

20 S. R. Kirk, N. W. Luedtke and Y. Tor, J. Am. Chem. Soc. 2000, 122, 980.

21 M. Kaiser, M. Sainlos, J-M. Lehn, S. Bombard and M-P. Teulade-Fichou, ChemBioChem 2006, 7, 321.

22 a) M. Eriksson and B. Nordén, Methods Enzymol. 2001, 340, 68; b) S. R. Ramisetty and A. M. Baranger, Bioorg. Med. Chem. Lett. 2010, 20, 3134.

23 B. S. Sproat, in Methods in Molecular Biology. Oligonucleotide Synthesis: Methods and Applications, Vol. 288 (Ed. P. Herdewijn), Humana Press, Totowa, N.J., 2005, pp. 17-31. 


\section{Text and figure for the Table of Contents}

Guanidinylation of the aminoglycoside moiety of ligands for the stem-loop secondary structure of Tau pre-mRNA modifies their RNA-binding properties.

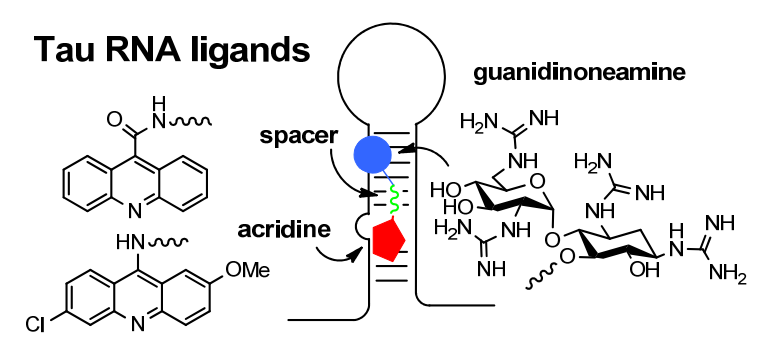

Keywords: combinatorial chemistry $\bullet$ template synthesis $\bullet$ molecular recognition $\bullet$ RNA structure $\bullet$ RNA ligands 